\title{
Temporal and spatial variability of ammonia in urban and agricultural regions of northern Colorado, United States
}

\author{
Yi Li ${ }^{1, \text { a }}$, Tammy M. Thompson ${ }^{2}$, Martin Van Damme ${ }^{3}$, Xi Chen ${ }^{1}$, Katherine B. Benedict ${ }^{1}$, Yixing Shao ${ }^{1}$ Derek Day $^{2}$, \\ Alexandra Boris ${ }^{1}$, Amy P. Sullivan ${ }^{1}$, Jay Ham ${ }^{4}$, Simon Whitburn ${ }^{3}$, Lieven Clarisse ${ }^{3}$, Pierre-François Coheur ${ }^{3}$, and \\ Jeffrey L. Collett Jr. ${ }^{1}$ \\ ${ }^{1}$ Department of Atmospheric Science, Colorado State University, Fort Collins, CO, USA \\ ${ }^{2}$ Cooperative Institute for Research in the Atmosphere/NPS, Colorado State University, Fort Collins, CO, USA \\ ${ }^{3}$ Atmospheric Spectroscopy, Université Libre de Bruxelles (ULB), Brussels, Belgium \\ ${ }^{4}$ Department of Soil \& Crop Sciences, Colorado State University, Fort Collins, CO, USA \\ ${ }^{a}$ now at: Arizona Department of Environmental Quality, Air Quality Division, Phoenix, AZ, USA
}

Correspondence to: Jeffrey L. Collett Jr. (collett@atmos.colostate.edu)

Received: 12 November 2016 - Discussion started: 23 November 2016

Revised: 4 April 2017 - Accepted: 7 April 2017 - Published: 22 May 2017

\begin{abstract}
Concentrated agricultural activities and animal feeding operations in the northeastern plains of Colorado represent an important source of atmospheric ammonia $\left(\mathrm{NH}_{3}\right)$. The $\mathrm{NH}_{3}$ from these sources contributes to regional fine particle formation and to nitrogen deposition to sensitive ecosystems in Rocky Mountain National Park (RMNP), located $\sim 80 \mathrm{~km}$ to the west. In order to better understand temporal and spatial differences in $\mathrm{NH}_{3}$ concentrations in this source region, weekly concentrations of $\mathrm{NH}_{3}$ were measured at 14 locations during the summers of 2010 to 2015 using Radiello passive $\mathrm{NH}_{3}$ samplers. Weekly (biweekly in 2015) average $\mathrm{NH}_{3}$ concentrations ranged from 2.66 to $42.7 \mu \mathrm{g} \mathrm{m}^{-3}$, with the highest concentrations near large concentrated animal feeding operations (CAFOs). The annual summertime mean $\mathrm{NH}_{3}$ concentrations were stable in this region from 2010 to 2015, providing a baseline against which concentration changes associated with future changes in regional $\mathrm{NH}_{3}$ emissions can be assessed. Vertical profiles of $\mathrm{NH}_{3}$ were also measured on the $300 \mathrm{~m}$ Boulder Atmospheric Observatory (BAO) tower throughout 2012. The highest $\mathrm{NH}_{3}$ concentration along the vertical profile was always observed at the $10 \mathrm{~m}$ height (annual average concentration of $4.63 \mu \mathrm{g} \mathrm{m}^{-3}$ ), decreasing toward the surface $\left(4.35 \mu \mathrm{g} \mathrm{m}^{-3}\right)$ and toward higher altitudes $\left(1.93 \mu \mathrm{g} \mathrm{m}^{-3}\right)$. The $\mathrm{NH}_{3}$ spatial distributions measured using the passive samplers are compared with $\mathrm{NH}_{3}$ columns retrieved by the Infrared Atmospheric Sounding Interferometer (IASI) satellite and concentrations simulated
\end{abstract}

by the Comprehensive Air Quality Model with Extensions (CAMx). The satellite comparison adds to a growing body of evidence that IASI column retrievals of $\mathrm{NH}_{3}$ provide very useful insight into regional variability in atmospheric $\mathrm{NH}_{3}$, in this case even in a region with strong local sources and sharp spatial gradients. The CAMx comparison indicates that the model does a reasonable job simulating $\mathrm{NH}_{3}$ concentrations near sources but tends to underpredict concentrations at locations farther downwind. Excess $\mathrm{NH}_{3}$ deposition by the model is hypothesized as a possible explanation for this trend.

\section{Introduction}

As the most abundant basic gas in the atmosphere, ammonia $\left(\mathrm{NH}_{3}\right)$ can neutralize ambient acidic species, such as sulfuric acid $\left(\mathrm{H}_{2} \mathrm{SO}_{4}\right)$ and nitric acid $\left(\mathrm{HNO}_{3}\right)$, to form ammonium salts, which are the dominant inorganic compounds in ambient $\mathrm{PM}_{2.5}$ (particulate matter with aerodynamic diameter less than $2.5 \mu \mathrm{m}$ ). $\mathrm{PM}_{2.5}$ has been linked to adverse effects on human health (Davidson et al., 2005; Schwartz and Neas, 2000; Lelieveld et al., 2015) and regional visibility reduction (Park et al., 2006) and also impacts climate via direct and indirect changes in radiative forcing (Langridge et al., 2012; Parry et al., 2007). While the atmospheric lifetime of $\mathrm{NH}_{3}$ is short (on the order of hours to days due to rapid dry deposition and particle-forming chemical reactions), ammonium 
$\left(\mathrm{NH}_{4}^{+}\right)$salts are mainly found in submicron aerosol particles and have longer atmospheric lifetimes (on the order of several days) so that they can be transported to remote areas away from $\mathrm{NH}_{3}$ sources (Aneja et al., 2001; Fowler et al., 1998; Ianniello et al., 2011). Dry and wet deposition of $\mathrm{NH}_{3}$ and $\mathrm{NH}_{4}^{+}$also play an important role in the adverse effects of increased nitrogen deposition to sensitive ecosystems (Asman et al., 1998; Beem et al., 2010; Benedict et al., 2013b; Horii et al., 2006; Paulot et al., 2013). Li et al. (2016) analyzed wet and dry deposition of reactive nitrogen across the US and found that reduced nitrogen, derived from $\mathrm{NH}_{3}$ emissions, now constitutes the majority of inorganic nitrogen deposition in most regions.

It is widely believed that agriculture represents the largest source of atmospheric $\mathrm{NH}_{3}$ globally, but at smaller spatial scales the influence of agriculture varies greatly. Sutton et al. (2013) estimated that $57 \%$ of global atmospheric $\mathrm{NH}_{3}$ is emitted from livestock and crops, while the US Environmental Protection Agency (EPA) attributed over $82 \%$ of $\mathrm{NH}_{3}$ emissions in the US to the agricultural sector in the $2014 \mathrm{Na}-$ tional Emissions Inventory (NEI, https://www.epa.gov/airemissions). Hertel et al. (2006) also found that deposition of atmospheric $\mathrm{NH}_{3}$ near an intensive agricultural area would dominate the overall load of reactive nitrogen $(\mathrm{N})$ from the atmosphere. Agricultural $\mathrm{NH}_{3}$ emissions have become one of the most prominent air pollution problems in recent years and have given rise to growing concerns (Aneja et al., 2006; Pan et al., 2012; Bauer et al., 2016). Within the US, efforts to routinely monitor $\mathrm{NH}_{3}$ concentrations have been growing via the Ammonia Monitoring Network (AMON; http://nadp.sws.uiuc.edu/). $\mathrm{NH}_{3}$ can now be considered as a precursor to $\mathrm{PM}_{2.5}$ in the state implementation planning process for meeting the national ambient air quality standards, and voluntary reductions in agricultural $\mathrm{NH}_{3}$ emissions have been prioritized as part of efforts to reduce reactive nitrogen deposition in Rocky Mountain National Park (http://www.rmwarningsystem.com/Reducing). Besides the dominant contributions from agricultural sources, ambient $\mathrm{NH}_{3}$ also originates from other sources such as vehicles with three-way catalysts (Shelef and Gandhi, 1974; Chang et al., 2016). Biomass burning (such as wildfires) is another important source of $\mathrm{NH}_{3}$ (Benedict et al., 2017): in the 2014 US NEI, wildfires make up nearly $4.3 \%$ of national $\mathrm{NH}_{3}$ emissions.

The northeastern plains of Colorado include the DenverFort Collins urban corridor along the Front Range and a large agricultural region reaching eastward toward the border with Nebraska. This area has been recognized as an important $\mathrm{NH}_{3}$ emission source region, and the largest reduced nitrogen source near Rocky Mountain National Park (RMNP; Benedict et al., 2013c; Ellis et al., 2013). According to the 2002 Front Range $\mathrm{NH}_{3}$ emission inventory, $\mathrm{NH}_{3}$ emissions from the Front Range were $10288 \mathrm{t} \mathrm{yr}^{-1}$ from livestock and $5183 \mathrm{t} \mathrm{yr}^{-1}$ from fertilizer application, which accounted for 30 and $27 \%$ of Colorado's $\mathrm{NH}_{3}$ emissions, re- spectively (according to RMNP Initiative - Nitrogen Deposition Reduction Contingency Plan, 2010). The Rocky Mountain Atmospheric Nitrogen and Sulfur (RoMANS) studies (https://www.nature.nps.gov/air/; Beem et al., 2010; Benedict et al., 2013c; Malm et al., 2013, 2016; Thompson et al., 2015), conducted in 2006 and 2009, showed that together $\mathrm{NH}_{3}$ and $\mathrm{NH}_{4}^{+}$contributed approximately $50 \%$ of the total reactive nitrogen deposition (both wet and dry) in RMNP, with the remainder coming from dry and wet deposition of nitrate and organic nitrogen (Benedict et al., 2013a). The highest concentrations of particulate $\mathrm{NH}_{4}^{+}$measured during RoMANS were associated with upslope transport from the east side of RMNP, indicating major sources of $\mathrm{NH}_{3}$ to RMNP are located in the northeastern plains of Colorado (Benedict et al., 2013c; Beem et al., 2010; Eilerman et al., 2016). In 2010, an effort was initiated to map the $\mathrm{NH}_{3}$ concentrations in northern Colorado and significant $\mathrm{NH}_{3}$ spatial differences were found, with averages ranging from $3.43 \mu \mathrm{g} \mathrm{m}^{-3}$ at rural grasslands to $10.7 \mu \mathrm{g} \mathrm{m}^{-3}$ at suburbanurban sites and $31.5 \mu \mathrm{g} \mathrm{m}^{-3}$ near an area of concentrated animal feeding operations (CAFOs; Day et al., 2012).

Due to the short atmospheric lifetime and high dry deposition velocity of $\mathrm{NH}_{3}$, there are many factors, such as the height of the boundary layer, surface properties, location of sources, local advection, and the vertical mixing rate, that influence spatial (horizontal and vertical) distributions of $\mathrm{NH}_{3}$ concentrations. This complex dependence of $\mathrm{NH}_{3}$ concentrations on atmospheric conditions and deposition variability results in great uncertainties of $\mathrm{NH}_{3}$ concentrations in global and regional atmospheric chemistry models (Sutton et al., 2008; Zhu et al., 2013). Several model performance evaluations (MPEs) have found model predictions of $\mathrm{NH}_{3}$ concentrations in the western US to be low (Rodriguez et al., 2011; Thompson et al., 2015; Battye et al., 2016). Rodriguez et al. (2011) and Thompson et al. (2015) utilized the Comprehensive Air Quality Model with Extensions (CAMx); Battye et al. (2016), meanwhile, ran a different photochemical model (CMAQ), and utilized emissions inventories generated with less focus on the precise spatial positioning of agricultural sector emissions in the InterMountain West. Evaluation of $\mathrm{NH}_{3}$ concentration prediction performance in larger scale models has suggested that uncertainty in emissions inventories is a cause of $\mathrm{NH}_{3}$ concentration underestimation in the west (Zhu et al., 2013; Heald et al., 2012). Van Damme et al. (2015) used measured $\mathrm{NH}_{3}$ data from the US, China, Africa, and Europe (ground-based and airborne observations) and compared these data with IASI$\mathrm{NH}_{3}$ columns. During the DISCOVER-AQ campaign, Sun et al. (2015) also compared in situ observations (airborne and vehicle-based) with Tropospheric Emission Spectrometer (TES) $\mathrm{NH}_{3}$ columns. Both comparisons demonstrated fair agreement between in situ measurements and satellite total columns, indicating that $\mathrm{NH}_{3}$ data from in situ measurements and satellite retrievals are reliable. The discrepancy between model predictions and observations of $\mathrm{NH}_{3}$ concentrations 
Table 1. Summary of sampling site locations and dates.

\begin{tabular}{|c|c|c|c|c|c|c|c|}
\hline ID & Site name & Type & Latitude & Longitude & Elevation (m) & Year $^{1}$ & Sampler type \\
\hline LE & Louisville & Suburban & 39.987 & -105.151 & 1698 & 11 & Passive \\
\hline FC_W & Fort Collins_West & Suburban & 40.589 & -105.148 & 1570 & $\begin{array}{r}10,11,12 \\
13,14,15\end{array}$ & Passive/URG \\
\hline LD & Loveland & Suburban & 40.438 & -105.127 & 1582 & $\begin{array}{r}10,11,12 \\
13,14,15\end{array}$ & Passive \\
\hline BAO & BAO Tower & Suburban & 40.050 & -105.004 & 1584 & $12^{2}$ & Passive/URG \\
\hline GC & Golf Course & Golf course & 40.426 & -105.107 & 1551 & $\begin{array}{r}10,11,12,13,14,15 \\
13,14,15\end{array}$ & Passive \\
\hline FC_E & Fort Collins_East & Suburban-agricultural & 40.591 & -104.928 & 1562 & $12,13,14$ & Passive \\
\hline SE & Severance & Suburban-agricultural & 40.572 & -104.836 & 1550 & $12,13,14,15$ & Passive \\
\hline GY & Greeley & Suburban-agricultural & 40.389 & -104.751 & 1492 & $\begin{array}{r}10,11,12,13,14,15 \\
13,14,15\end{array}$ & Passive \\
\hline $\mathrm{NN}$ & Nunn & Rural & 40.821 & -104.701 & 1644 & $\begin{array}{r}11,12,13,14,15 \\
14,15\end{array}$ & Passive \\
\hline $\mathrm{BE}$ & Briggsdale & Rural & 40.635 & -104.330 & 1481 & $\begin{array}{r}10,11,12 \\
13,14,15\end{array}$ & Passive \\
\hline RH & Ranch & Rural & 40.473 & -104.317 & 1475 & 10 & Passive \\
\hline AT & Ault & Rural-agricultural & 40.612 & -104.709 & 1514 & $\begin{array}{r}11,12,13,14,15 \\
14,15\end{array}$ & Passive \\
\hline KY & Kersey & Rural-agricultural & 40.377 & -104.532 & 1403 & $\begin{array}{r}10,11,12,13,14,15 \\
13,14,15\end{array}$ & Passive \\
\hline $\mathrm{BH}$ & Brush & Rural-agricultural & 40.313 & -103.602 & 1286 & $\begin{array}{r}10,11,12 \\
13,14,15\end{array}$ & Passive/URG \\
\hline
\end{tabular}

${ }^{1}$ Sampling period: 20 May-2 September 2010; 2 June-31 August 2011; 21 June-29 August 2012; 30 May-29 August 2013 ; 29 May-28 August 2014 ; 26 May-1 September 2015.

${ }^{2}$ Even though one full year of measurements was conducted at the BAO site (13 December 2011-9 January 2013), only the summer average NH 3 concentration (19 June-30

August 2012) was reported in Fig. 1 to compare with the $\mathrm{NH}_{3}$ concentrations at other sites.

suggests that variability in the spatial and/or temporal distribution of $\mathrm{NH}_{3}$ is not captured by current emissions inventories or model inputs, and additional understanding of atmospheric $\mathrm{NH}_{3}$ distributions, for example, with height above ground level, is needed. Vertical $\mathrm{NH}_{3}$ profiles have previously been reported from airborne studies such as CalNex (Nowak et al., 2012; Schiferl et al., 2014), the DISCOVERAQ campaign (Sun et al., 2015; Müller et al., 2014), and from measurements made at the Canadian oil sands (Shephard et al., 2015). These studies have found strong variation of $\mathrm{NH}_{3}$ concentration above ground, but do not provide a sufficient basis to characterize the general vertical distribution of $\mathrm{NH}_{3}$ with limited sampling periods.

The primary goal of this study is to investigate the spatial and temporal variability of $\mathrm{NH}_{3}$ concentrations in the northeastern plains of Colorado. This effort builds upon the earlier efforts of Benedict et al. (2013c), Day et al. (2012), and Battye et al. (2016) to look at patterns of spatial variability across several years with different meteorology and source strength (e.g., years with and without active fire seasons) and to identify any multi-year trends in regional $\mathrm{NH}_{3}$ concentrations. Year-round measurements of the vertical profile of $\mathrm{NH}_{3}$ measured using a $300 \mathrm{~m}$ tower near Erie, Colorado, will also provide new insight into the vertical profile of $\mathrm{NH}_{3}$ concentrations in the lower atmosphere and its change with season. The in situ surface and tower measurements will also be compared to $\mathrm{NH}_{3}$ remote sensing measurements from the Infrared Atmospheric Sounding Interferometer (IASI) satellite (Whitburn et al., 2016; Van Damme et al., 2015) and predictions from CAMx to provide insight into the regional performance of each. Many recent and past MPEs have utilized special studies, such as the one presented in this paper, to evaluate photochemical model performance with respect to $\mathrm{NH}_{3}$. Overall, our results are useful for determining important sources contributing to regional nitrogen deposition, validating emission inventories and concentration predictions for atmospheric chemistry models, and setting a baseline against which concentration changes resulting from future emission changes can be assessed.

\section{Methodology}

\subsection{Site descriptions}

The northeastern plains of Colorado are an intensive agricultural area with many CAFOs, including beef cattle feedlots and dairy operations. The densely populated Front Range urban corridor is located just west of this area, and just east of the Rocky Mountains. In order to gain information about spatial variability of northeast Colorado $\mathrm{NH}_{3}$ concentrations, fourteen monitoring sites were selected in the region according to land use categories and distance from 
known, major $\mathrm{NH}_{3}$ sources (Table 1). Five suburban monitoring sites located in the Front Range urban corridor are representative of areas with little local agricultural influence, especially from animal feeding operations: Louisville (LE), western Fort Collins (FC_W), Loveland (LD), Loveland Golf Course (GC), and the Boulder Atmospheric Observatory (BAO) tower. Three rural sites (Nunn, NN; Briggsdale, BE; and Ranch, RH), located close to the northern boundary of Colorado with Wyoming, are grassland sites with minimal local agricultural influence. Three suburban sites (eastern Fort Collins, FC_E; Severance, SE; and Greeley, GY) as well as three rural sites (Ault, AT; Kersey, KY; and Brush, BH) represent areas close to and likely significantly influenced by agricultural activities, including animal feeding operations. For example, the KY site is located approximately $0.4 \mathrm{~km}$ from a large beef cattle feedlot (about 100000 cattle capacity).

The BAO tower is a $300 \mathrm{~m}$ meteorological tower situated in the southern part of the sampling area $\left(40.050^{\circ} \mathrm{N}\right.$, $\left.105.004^{\circ} \mathrm{W}\right)$. It has been owned and operated by the National Oceanic and Atmospheric Administration (NOAA) for more than 25 years (http://www.esrl.noaa.gov/psd). The tower is surrounded by natural grass and wheat fields, and is approximately $400 \mathrm{~m}$ west of Interstate 25 and $30 \mathrm{~km}$ north of downtown Denver.

\subsection{Sample collection and validation}

In order to obtain spatial and vertical distributions of $\mathrm{NH}_{3}$ concentrations, two sampling campaigns were carried out in the northeastern plains of Colorado using Radiello passive $\mathrm{NH}_{3}$ samplers and URG (University Research Glassware, Inc.) denuder/filter-pack systems. The Radiello passive $\mathrm{NH}_{3}$ sampler consists of a cartridge adsorbent (part number: RAD168), a blue microporous cylindrical diffusive body (part number: RAD1201), and a vertical adapter (part number: RAD 122). All Radiello sampler components were obtained from Sigma Aldrich (http://www.sigmaaldrich.com). Measurements of the spatial $\mathrm{NH}_{3}$ distribution were conducted each summer from 2010 to 2015. During the first summer (2010), measurements were made at nine sites; in 2011, the Ranch (RH) site was removed and the LE and NN sites were added; in 2012, the LE site was removed; and two sites, FC_E and SE, were added in 2013. The two site removals in 2013 (RH and LE) and FC_E removal in 2015 were both due to property access issues. In a second campaign, measurements of vertical $\mathrm{NH}_{3}$ concentration profiles were conducted at the BAO tower from December 2011 to January 2013.

\subsection{Passive sampler}

Passive ammonia samplers have been used in several previous studies because of their reliability, low labor intensity, simplicity and lack of power requirement (Cisneros et al., 2010; Day et al., 2012; Meng et al., 2011; Reche et al., 2012; Puchalski et al., 2011). During sample collection, the sampler was protected from precipitation and direct sunlight by an inverted plastic bucket. Ambient $\mathrm{NH}_{3}$ diffuses through a microporous diffusive body surface and is captured as $\mathrm{NH}_{4}^{+}$ by a cartridge impregnated with phosphoric acid $\left(\mathrm{H}_{3} \mathrm{PO}_{4}\right)$. A weekly sampling campaign period was implemented in each summer during the study: 20 May to 2 September 2010, 2 June to 31 August 2011, 21 June to 29 August 2012, 30 May to 29 August 2013, and 29 May 29 to 28 August 2014. Biweekly samples were collected from 26 May to 1 September 2015. At the $\mathrm{BAO}$ tower, $\mathrm{NH}_{3}$ was sampled at nine heights: $1,10,22,50,100,150,200,250$, and $300 \mathrm{~m}$. Vertical profiles were measured across 2-week sampling periods from 13 December 2011 to 9 January 2013, except when weekly measurements were conducted from 19 June to 30 August 2012, when higher concentrations were anticipated. Passive samplers were prepared in an $\mathrm{NH}_{3}$-free laminar flow hood (Envirco Corporation) and sealed for transport to the field. More detailed information regarding sampler preparation can be obtained in Day et al. (2012).

The ambient $\mathrm{NH}_{3}$ concentration was calculated based on the characteristics of the passive sampler and the diffusivity of $\mathrm{NH}_{3}$ in the atmosphere $\left(D_{\mathrm{NH}_{3}}\right)$, which is a function of local temperature $(T)$ and ambient pressure $(P)$, and can be expressed using Eq. (1):

$D_{\mathrm{NH}_{3}}(T, P)=D_{0,1} \times\left(\frac{P_{0}}{P}\right) \times\left(\frac{T}{T_{0}}\right)^{1.81}$,

where $D_{0,1}=0.1978 \mathrm{~cm}^{2} \mathrm{~s}^{-1}$ at $T_{0}=273 \mathrm{~K}\left(0^{\circ} \mathrm{C}\right)$ and $P_{0}=1 \mathrm{~atm}$ (Massman, 1998). Then, the diffusional flow rate through the $\mathrm{NH}_{3}$ passive sampler $\left(Q_{\mathrm{NH}_{3}}\right)$ is given by Eq. (2):

$Q_{\mathrm{NH}_{3}}=D_{\mathrm{NH}_{3}}(T, P) \times \frac{A}{\Delta X}$,

where $A$ is the passive sampler effective cross-sectional area and $\Delta X$ is the passive sampler diffusion distance. For the Radiello $\mathrm{NH}_{3}$ passive sampler, $A / \Delta X$ represents the geometric constant for radial flow and has been reported to be $14.2 \mathrm{~cm}$, based on actual physical measurements (Day et al., 2012; Puchalski et al., 2011), which differs from the manufacturer's description (http://www.radiello.com/english). Each diffusional flow rate $\left(Q_{\mathrm{NH}_{3}}\right)$ was calculated for the averaged $T$ and $P$ for each interval sampling period. Finally, the $\mathrm{NH}_{3}$ concentration in the air $\left(C_{\mathrm{NH}_{3}}\right)$ is calculated from the diffusional flow rate $\left(Q_{\mathrm{NH}_{3}}\right)$, the duration of sampling 
time $(t)$ and the mass of $\mathrm{NH}_{3}$ collected on the cartridge $\left(m_{\mathrm{NH}_{3}}\right)$ as shown in Eq. (3):

$C_{\mathrm{NH}_{3}}=\frac{m_{\mathrm{NH}_{3}}}{t \times Q_{\mathrm{NH}_{3}}}$.

For the northeastern plains network, hourly temperature data were obtained from nearby CoAGMET weather stations (http://www.coagmet.com/; Table S1 in the Supplement). The distance between the $\mathrm{NH}_{3}$ measurement sites and the nearby meteorological stations referenced in the paper were from $0.1 \mathrm{~km}$ (KSY01 to $\mathrm{KY}$ ) to $68.1 \mathrm{~km}$ (BRG01 to $\mathrm{BH}$ ), with an average value of $16.5 \mathrm{~km}$. The average meteorological record was fairly consistent from year to year. The ambient pressure was calculated based on the elevation of each site. At the BAO tower, temperature, and relative humidity were measured by battery-powered sensors (EBI20-TH1, EBRO Inc. Ingolstadt, Germany; http://shop.ebro.com/) colocated with the $\mathrm{NH}_{3}$ passive samplers at each sampling height.

\subsection{URG denuder/filter-pack sampler}

During the same sampling periods as the $\mathrm{NH}_{3}$ passive samplers, URG denuder/filter-pack sampling systems were also installed during select campaign years at the FC_W, GY, and $\mathrm{BAO}$ tower sites to measure the concentrations of gaseous $\mathrm{NH}_{3}$ and $\mathrm{HNO}_{3}$, as well as fine particulate inorganic ions. Air was drawn first through a Teflon-coated $\mathrm{PM}_{2.5}$ cyclone $\left(D_{50}=2.5 \mu \mathrm{m}\right)$ at the inlet, followed by two annular denuders connected in series. The first denuder was coated with sodium carbonate $\left(\mathrm{Na}_{2} \mathrm{CO}_{3}\right)$ solution $\left(10 \mathrm{~g}\right.$ of $\mathrm{Na}_{2} \mathrm{CO}_{3}$ and $10 \mathrm{~g}$ of glycerol dissolved in $500 \mathrm{~mL}$ of $18.2 \mathrm{M} \Omega \mathrm{cm}$ deionized water and $500 \mathrm{~mL}$ methanol) to collect gaseous $\mathrm{HNO}_{3}$ and sulfur dioxide $\left(\mathrm{SO}_{2}\right)$. The second denuder was coated with a phosphorous acid $\left(\mathrm{H}_{3} \mathrm{PO}_{3}\right)$ solution $(10 \mathrm{~g}$ of $\mathrm{H}_{3} \mathrm{PO}_{3}$ dissolved in $100 \mathrm{~mL}$ of deionized water and $900 \mathrm{~mL}$ methanol) to collect gaseous $\mathrm{NH}_{3}$ in the atmosphere. The air was then drawn through a filter pack containing a $47 \mathrm{~mm}$ nylon filter (Nylasorb, pore size $1 \mu \mathrm{m}$, Pall Corporation) to collect fine particles, followed by a backup $\mathrm{H}_{3} \mathrm{PO}_{3}$-coated denuder to capture any $\mathrm{NH}_{3}$ re-volatilized from $\mathrm{NH}_{4}^{+}$salt particles collected on the nylon filter. The URG samplers were changed at the same time as the passive samplers during each site visit. The air flow rate was controlled by a URG mass flow-controlled pump; the total flow rate through the system was nominally $3 \mathrm{~L} \mathrm{~min}^{-1}$ at FC_W, GY, and BAO. The URG sampling system has been used widely in previous studies because of its validated performance in sampling gases and particles (Bari et al., 2003; Beem et al., 2010; Benedict et al., 2013b; Lee et al., 2008; Li et al., 2014; Lin et al., 2006) and was used as a reference method for evaluating the performance of the $\mathrm{NH}_{3}$ passive samplers.

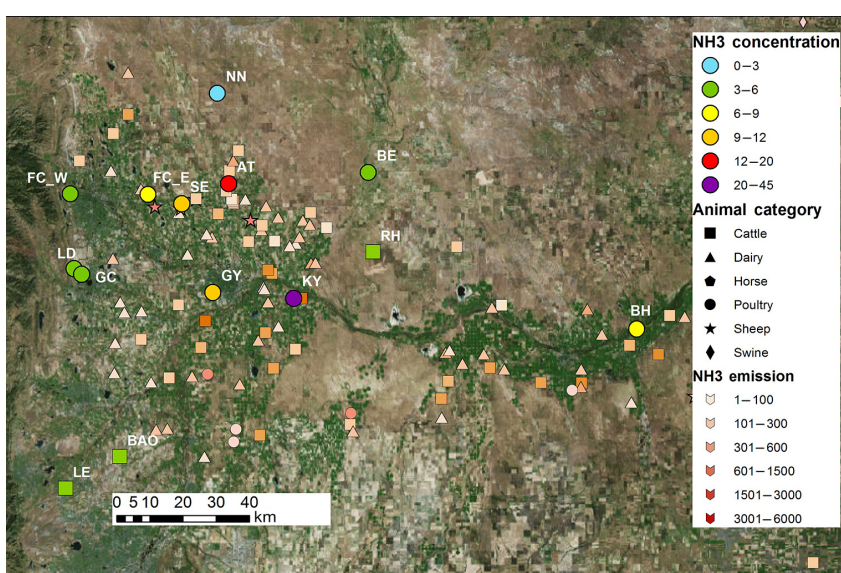

Figure 1. $\mathrm{NH}_{3}$ concentrations (unit: $\mu \mathrm{g} \mathrm{m}^{-3}$ ) and feedlot emissions (unit: $\mathrm{t} \mathrm{yr}^{-1}$ ) in northeast Colorado. All sites indicated by circles include at least 3 years of measurements in summer. $\mathrm{NH}_{3}$ concentrations at the RH, LE, and BAO sites (squares) were only measured in the summers of 2010, 2011, and 2012, respectively. The predicted annual $\mathrm{NH}_{3}$ emissions are calculated based on Eq. (4).

\subsection{Sample analysis and evaluation}

Passive samplers and URG denuders were extracted on arrival in the lab at Colorado State University (CSU). The URG denuders were extracted with $10 \mathrm{~mL}$ deionized water; the Nylon filters and passive sampler cartridges were ultrasonically extracted for $55 \mathrm{~min}$ in 6 and $10 \mathrm{~mL}$ deionized water, respectively. Passive sampler and $\mathrm{H}_{3} \mathrm{PO}_{3}$-coated denuder extracts were analyzed by ion chromatography for $\mathrm{NH}_{4}^{+}, \mathrm{Na}_{2} \mathrm{CO}_{3}$-coated denuder extracts were analyzed for $\mathrm{NO}_{3}^{-}$and $\mathrm{SO}_{4}^{2-}$, and Nylon filter extracts were analyzed for cations $\left(\mathrm{Na}^{+}, \mathrm{NH}_{4}^{+}, \mathrm{K}^{+}, \mathrm{Mg}^{2+}\right.$, and $\left.\mathrm{Ca}^{2+}\right)$ and anions $\left(\mathrm{Cl}^{-}\right.$, $\left.\mathrm{NO}_{3}^{-}, \mathrm{SO}_{4}^{2-}\right)$. Cations in the samples were separated with a $20 \mathrm{mM}$ methanesulfonic acid eluent $\left(0.5 \mathrm{~mL} \mathrm{~min}^{-1}\right)$ on a Dionex CS12A ion exchange chromatography column configured with a CSRS ULTRA II suppressor and detected using a Dionex conductivity detector. Anions in the samples were separated with an $8 \mathrm{mM}$ carbonate $/ 1 \mathrm{mM}$ bicarbonate eluent $\left(1 \mathrm{~mL} \mathrm{~min}{ }^{-1}\right)$ on a Dionex AS14A column followed by an ASRS ULTRA II suppressor and detected using a Dionex conductivity detector (Li et al., 2014).

Replicate Radiello passive samples were collected at FC_W (2011, weekly), BH (2012, 2013, and 2014, weekly), GY (2014, weekly; 2015, biweekly), KY (2014, weekly) and three different heights $(1,100$, and $300 \mathrm{~m})$ of the BAO tower (biweekly; weekly in summer) during the campaign to evaluate the performance of $\mathrm{NH}_{3}$ passive samplers under different $\mathrm{NH}_{3}$ concentrations and sampling periods. Comparison of replicate samples yielded good precision (see Fig. S1 in the Supplement) with a pooled relative standard deviation of $8.9 \%(n=288)$. The weekly and biweekly $\mathrm{NH}_{3}$ concentrations collected by passive samplers were also in good agree- 
Table 2. Summary of summer $\mathrm{NH}_{3}$ concentrations (units: $\mu \mathrm{g} \mathrm{m}^{-3}$ ) measured from 2010 to 2015 .

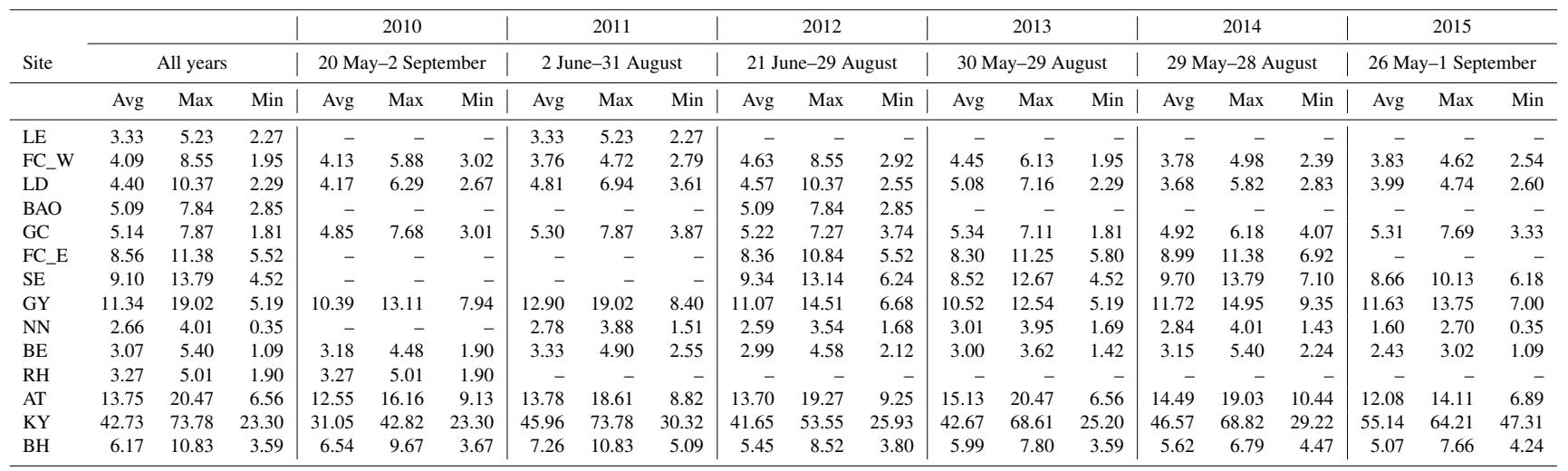

ment with measurements by co-located URG denuder samplers for the same sampling durations (a linear least-squares regression fit yielded a correlation coefficient $\left(R^{2}\right)$ between the two methods of 0.92 with a slope of 0.98 and a small positive intercept $\left(0.25 \mu \mathrm{g} \mathrm{m}^{-3}\right)$ with $n=136$ collocated measurements; Fig. S2). These findings are consistent with previous studies (Benedict et al., 2013b; Day et al., 2012; Puchalski et al., 2011). Field and laboratory blanks were collected throughout the research campaign and used to blank correct sample results and determine the minimum detection limits (MDLs). From the field blanks, the MDL was calculated to be $0.27 \mu \mathrm{g} \mathrm{m}^{-3}$ for a 1-week Radiello passive $\mathrm{NH}_{3}$ sample.

\subsection{Satellite retrievals of ammonia}

The Infrared Atmospheric Sounding Interferometer (IASI) is a passive infrared Fourier transform spectrometer onboard the MetOp platforms, operating in nadir (Clerbaux et al., 2009). IASI provides a quasi-global coverage twice a day with overpass times at around 09:30 and 21:30 (when crossing the Equator) at a relatively small pixel size (circle with $12 \mathrm{~km}$ diameter at nadir, distorted to ellipse-shaped pixels off-nadir). The combination of low instrumental noise $\left(\sim 0.2 \mathrm{~K}\right.$ at $950 \mathrm{~cm}^{-1}$ and $\left.280 \mathrm{~K}\right)$, a medium spectral resolution $\left(0.5 \mathrm{~cm}^{-1}\right.$ apodized $)$ and a continuous spectral coverage between 645 and $2760 \mathrm{~cm}^{-1}$ makes IASI a suitable instrument to measure various constituents of the atmosphere (Clarisse et al., 2011).

The IASI-NH $\mathrm{N}_{3}$ data set used in this work is based on a recently developed retrieval scheme presented in detail in Whitburn et al. (2016). The first step of the retrieval scheme is to calculate a so-called hyperspectral range index (HRI) for each IASI spectrum, which is representative of the amount of $\mathrm{NH}_{3}$. This HRI is subsequently converted into $\mathrm{NH}_{3}$ total columns using a neural network (NN) approach. It is an extension of the HRI method presented in Van Damme et al. (2014), who used two-dimensional look-up tables (LUTs) for the radiance-concentration conversion. The new NNbased method inherits the advantages of the LUT-based HRI method whilst providing several significant improvements such as (1) better sensitivity at low concentrations due to the large variation in temperature, pressure, and humidity vertical profiles in the retrieval; (2) a reduction of the reported positive bias of LUT retrieval at low concentrations; (3) the possible consideration of $\mathrm{NH}_{3}$ vertical profile information from third-party sources; and (4) a full uncertainty characterization of the retrieved column variables (Whitburn et al., 2016). The IASI sensitivity to $\mathrm{NH}_{3}$ is dependent on the thermal contrast (TC), defined as the temperature difference between the surface and the air at the surface. With a TC of 5,10 , and $15 \mathrm{~K}$, the detection limit at one sigma is respectively $6.3 \times 10^{15}, 3.3 \times 10^{15}$, and $2 \times 10^{15}$ molec. $\mathrm{cm}^{-2}$. In northern Colorado, the TC during the summer period for the morning overpass of IASI is around $10 \mathrm{~K}$.

\subsection{Ammonia modeling}

Chemical transport models are valuable tools for evaluating how various processes influence ambient air quality and pollutant deposition. They can be especially helpful in designing effective source control strategies for air quality improvement. Unfortunately, current models frequently have difficulties accurately simulating spatial concentrations of $\mathrm{NH}_{3}$ (Battye et al., 2016; Adelman et al., 2015). In addition to the typical model difficulties in accurately simulating transport, $\mathrm{NH}_{3}$ emissions are not well constrained (Zhu et al., 2013) and the parameterization of $\mathrm{NH}_{3}$ deposition is challenging (Bash et al., 2013; Pleim et al., 2013). In order to examine some of these issues, $\mathrm{NH}_{3}$ measurements from this study are compared to modeled concentrations from the Comprehensive Air Quality Model with Extensions (CAMx, http://www.camx.com/files/). CAMx, a photochemical model that simulates the emissions, transport, chemistry, and removal of chemical species in the atmosphere, is one of US EPA's recommended regional chemical transport models and is frequently used for air quality analysis (EPA, 2007, 2011). The 2011 modelled period presented here (version base_2011a), including inputs representing emissions and 
meteorology, was developed for the Intermountain West Data Warehouse (IWDW; Adelman et al., 2015); details on modeling protocol and model performance are available on the IWDW website (http://views.cira.colostate).

\section{Results and discussion}

\subsection{Spatial distributions of ammonia}

Large spatial differences in $\mathrm{NH}_{3}$ concentrations were found in the northeastern plains of Colorado with mean $\mathrm{NH}_{3}$ concentrations ranging from 2.66 to $42.7 \mu \mathrm{g} \mathrm{m}^{-3}$ as illustrated in Fig. 1. Also included in Fig. 1 are, for qualitative comparisons, estimated $\mathrm{NH}_{3}$ emissions from major feedlots in northeastern Colorado. The feedlots were classified into categories based on the type of animals raised (data were provided by the Colorado Department of Public Health and Environment) and $\mathrm{NH}_{3}$ emissions were calculated following Eq. 4:

$\mathrm{NH}_{3}$ Emission $=\sum($ Population $\times$ Emission Factor $)$,

where the $\mathrm{NH}_{3}$ emissions are the total $\mathrm{NH}_{3}$ emitted from each feedlot in tons per year (converted from kilograms to tons for Fig. 1), population is the animal population in each feedlot and the emission factor was specified for each kind of animal: 44.3, 38.1, 3.37, 0.27, 6.50, and $12.2 \mathrm{~kg} \mathrm{NH}_{3}$ head $\mathrm{yr}^{-1}$, for beef cattle, dairy cows, sheep, poultry, swine, and horses, respectively (USEPA, 2004; Todd et al., 2013). In total, $73 \%$ of the total regional feedlot emissions are contributed by beef feedlots. Many large sources are located within several tens of $\mathrm{km}$ to the south, east, and north of Greeley. Other large sources are located further east along the South Platte River with some smaller sources (mostly dairies) located further west in the sampling region, closer to the urban corridor. The lowest average ambient $\mathrm{NH}_{3}$ concentrations from 2010 to 2015 in the sampling network were found at remote grassland sites such as NN and BE: 2.66 and $3.07 \mathrm{\mu g} \mathrm{m}^{-3}$, respectively (Table 2). Concentrations of $\mathrm{NH}_{3}$ at suburban sites were somewhat higher than at these remote, rural sites, indicating possible impacts of human activities such as emissions from vehicles equipped with threeway catalytic converters, local waste treatment, and fertilization of yards and parks on local $\mathrm{NH}_{3}$ concentrations. The measured weekly average $\mathrm{NH}_{3}$ concentration at the Loveland Golf Course (GC) site was $5.14 \mu \mathrm{g} \mathrm{m}^{-3}$ with a range of 1.81 to $7.87 \mu \mathrm{g} \mathrm{m}^{-3}$, showing only slightly elevated values compared to $\mathrm{NH}_{3}$ concentrations at other nearby suburban sites (FC_W and LD), suggesting that golf course fertilization at this location is probably not a major, regional $\mathrm{NH}_{3}$ source. However, the $\mathrm{NH}_{3}$ concentrations at the $\mathrm{GC}$ were modestly higher (17\% on average) than $\mathrm{NH}_{3}$ sampled at the LD site during each summer measurement campaign (Table 2), suggesting that the contributions from fertilization of the golf lawn cannot be neglected. The highest ambient $\mathrm{NH}_{3}$ concen-

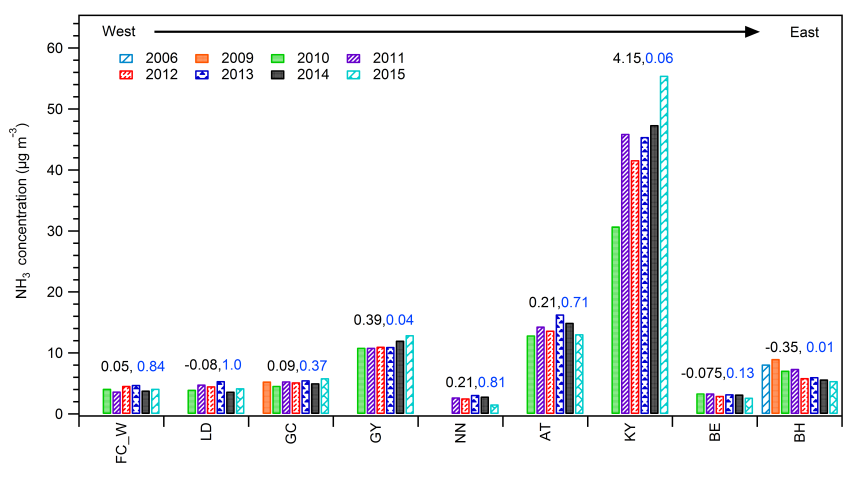

Figure 2. Average concentrations of $\mathrm{NH}_{3}$ in each summer (approximately June through August) across the nine sites. In 2006 (6 July10 August), ambient $\mathrm{NH}_{3}$ concentrations were sampled by a URG denuder (daily) at the BH site; in 2009 (11 June-27 August) ambient $\mathrm{NH}_{3}$ concentrations were sampled by a URG denuder (weekly) at the GC and BH sites; in 2010 (17 June-2 September), 2011 (16 June-31 August), 2012 (21 June-29 August), 2013 (20 June-29 August), 2014 (19 June-28 August) and 2015 (23 June-1 September), ambient $\mathrm{NH}_{3}$ concentrations were all sampled by Radiello $\mathrm{NH}_{3}$ passive samplers across all the sites. Trend analysis (annual concentration vs. time) was conducted at each site. The slope of the Theil regression and $p$ value for each site are labeled in black and blue.

trations were consistently observed at sites near extensive animal feeding operations. Compared to the remote sites (NN and $\mathrm{BE}$ ), an approximately 2- to 5 -fold increase in $\mathrm{NH}_{3}$ concentrations was observed at rural sites BH and AT (6.17 and $13.8 \mu \mathrm{g} \mathrm{m}^{-3}$ ), which were under the influence of nearby animal feeding operation emissions. A 15 -fold increase in mean $\mathrm{NH}_{3}$ concentrations was observed from the grassland $\mathrm{NN}$ and BE sites (2.66 and $3.07 \mu \mathrm{g} \mathrm{m}^{-3}$ ) to $\mathrm{KY}\left(42.73 \mu \mathrm{g} \mathrm{m}^{-3}\right)$, $0.4 \mathrm{~km}$ from a feedlot with almost 100000 cattle.

The interannual variation of average summertime $\mathrm{NH}_{3}$ concentrations sampled at each site spanning several years exhibited a statistically significant $(p<0.1)$ trend (Fig. 2) at three sites; six sites showed no significant trend. Both the GY and KY sites show increasing trends, while BH exhibits a decreasing trend. Trend analysis was conducted using Theil regression (Theil, 1992) and the Mann-Kendall test (Gilbert, 1987; Marchetto et al., 2013). We define an increasing (decreasing) trend as a positive (negative) slope of the Theil regression, while the statistical significance of a trend was determined by the Mann-Kendall test ( $p$ value). A 90th percentile significance level $(p<0.10)$ was assumed as in a previous study (Hand et al., 2012). The power of these analyses are limited by the relatively small number of measurement years to date; additional power for assessing interannual trends will become available as the measurement record lengthens. Data from the Colorado Agricultural Statistics Report (2015, http://www.nass.usda.gov/Statistics) indicate that Weld, Larimer, and Morgan counties (three major counties located in the northeastern plains of Colorado) did not show 


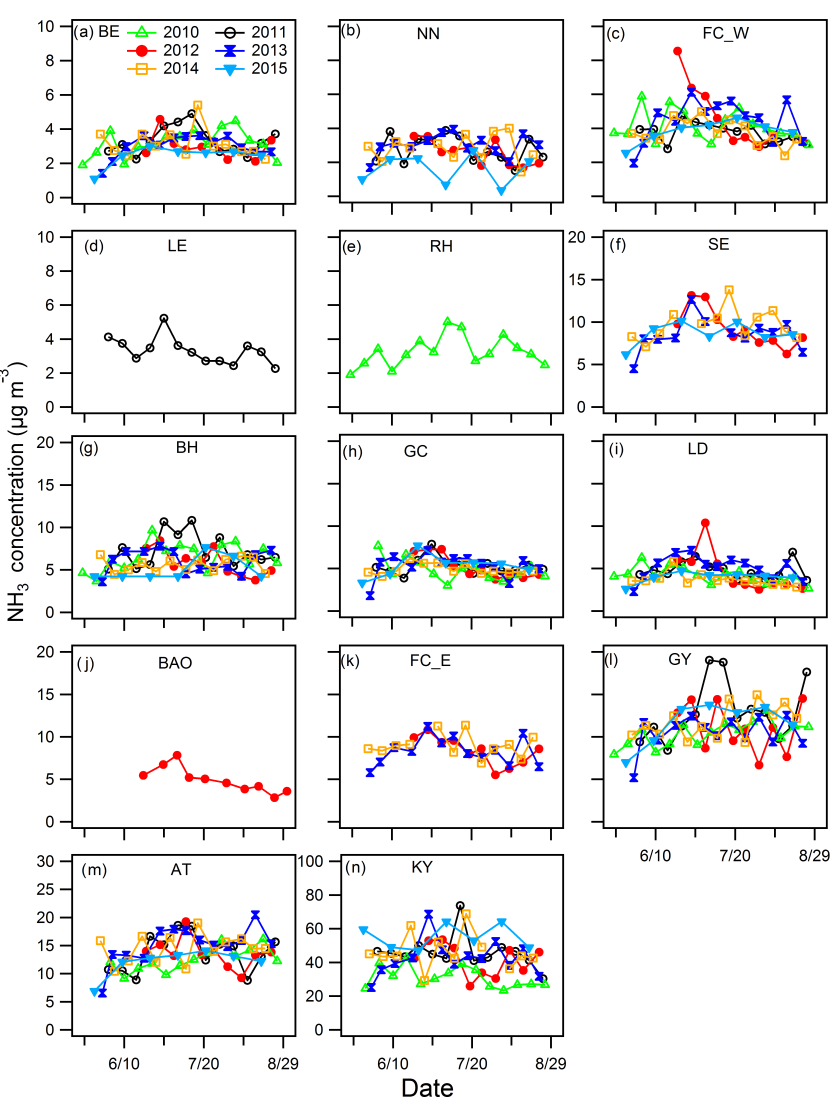

Figure 3. Temporal variations in $\mathrm{NH}_{3}$ concentrations (unit: $\mu \mathrm{g} \mathrm{m}^{-3}$ ) at each site from 2010 through 2015 . Note the differences in the $y$-axis values.

significant growth in livestock numbers between 2009 and 2014. The total annual numbers of beef cattle, milk cows, cattle, and calves in these counties were 986, 974, 996, 1065, 955 , and 936 thousand head, respectively, in the 6 years from 2009 to 2014.

A number of best management practices (BMPs; http://www.rmwarningsystem.com) are under evaluation to help agricultural producers in the region to lower $\mathrm{NH}_{3}$ emissions as part of efforts to reduce reactive nitrogen deposition in Rocky Mountain National Park. The baseline regional concentration information gathered here will be critical in helping to evaluate the success of future efforts to reduce $\mathrm{NH}_{3}$ emissions.

Weekly average atmospheric $\mathrm{NH}_{3}$ concentrations at each observation site are plotted for summers 2010-2015 in Fig. 3. These observations again show the general similarity, at a given location, of summertime concentrations across several years. Some variation from week to week is expected due to differences in meteorology. Emissions, for example, are dependent on the temperature, dispersion is influenced by turbulence and mixing layer depth, and removal is influenced by precipitation and turbulence. One clear outlier period is the elevated $\mathrm{NH}_{3}$ concentrations observed at $\mathrm{FC}_{-} \mathrm{W}$ at the begin- ning of summer 2012 (Fig. 3c). The maximum weekly average $\mathrm{NH}_{3}$ concentration at this site $\left(8.55 \mu \mathrm{g} \mathrm{m}^{-3}\right)$ was measured during 21-28 June 2012 and was more than 2 times the average $\mathrm{NH}_{3}$ concentration in $2010\left(4.13 \mu \mathrm{g} \mathrm{m}^{-3}\right)$ and 2011 $\left(3.76 \mu \mathrm{g} \mathrm{m}^{-3}\right.$; see Table 2$)$. This is supported by the satellite observation reported by IASI (see Sect. 3 and Fig. 7). During this elevated concentration period, the High Park Fire, one of the largest fires recorded in Colorado history at $353 \mathrm{~km}^{2}$ burned, was burning in the mountains west of Fort Collins and the city was frequently impacted by smoke. The fire was first spotted on 9 June 2012 and declared $100 \%$ contained on 1 July 2012 (https://inciweb.nwcg.gov). During the wildfire period, on-line instruments (Picarro $\mathrm{NH}_{3}$ analyzer and Teledyne $\mathrm{CO}$ analyzer) were also set up to measure $\mathrm{CO}$ and $\mathrm{NH}_{3}$ concentrations near the FC_W site. A significant correlation between $\mathrm{CO}$ and $\mathrm{NH}_{3}$ was found during the wildfire (Prenni et al., 2012; Benedict et al., 2017). The FC_W was site was the closest site to the High Park Fire and normally has relatively low ambient $\mathrm{NH}_{3}$ concentration. The $\mathrm{NH}_{3}$ emitted from the High Park Fire may also have reached other, more distant sites downwind; however, enhanced $\mathrm{NH}_{3}$ concentrations at these sites from other nearby sources and the greater dilution of the smoke plume as it travels further downwind make it difficult to identify any impacts of the wildfire at these locations. Elevated $\mathrm{NH}_{3}$ concentrations in the High Park Fire plume are evidence of the importance of wild and prescribed burning as a source of atmospheric $\mathrm{NH}_{3}$, reinforcing similar findings from previous studies (Coheur et al., 2009; Prenni et al., 2014; Sutton et al., 2000; Whitburn et al., 2015; Luo et al., 2015).

\subsection{Vertical distribution of ammonia}

While surface measurements of $\mathrm{NH}_{3}$ concentrations remain uncommon, measurements of vertical profiles of $\mathrm{NH}_{3}$ concentrations above the surface are more rare, with the exception of a small number of aircraft measurements over limited time frames as mentioned in the introduction. Time series of vertical profiles of ambient $\mathrm{NH}_{3}$ concentrations measured at the BAO tower across the full year of 2012 are shown in Fig. 4. During most sampling periods, the $\mathrm{NH}_{3}$ concentration exhibited a maximum at $10 \mathrm{~m}$ decreasing both toward the lowest $(1 \mathrm{~m})$ measurement point and with height above $10 \mathrm{~m}$. The minimum concentration was observed at the highest measurement point at the top $(300 \mathrm{~m})$ of the BAO tower. While the major sources of $\mathrm{NH}_{3}$ are surface emissions, it is not surprising to see a gradient of decreasing concentration near the surface at this location where local emissions are expected to be small and the net local flux represents surface deposition (Pul et al., 2009). The long time duration of the integration period (1-2 weeks) in this study precludes a meaningful determination of surface removal rates based on the observed concentration gradient.

Seasonal variations in the vertical profile of $\mathrm{NH}_{3}$ are depicted in Fig. 5 with March, April, and May defined as 


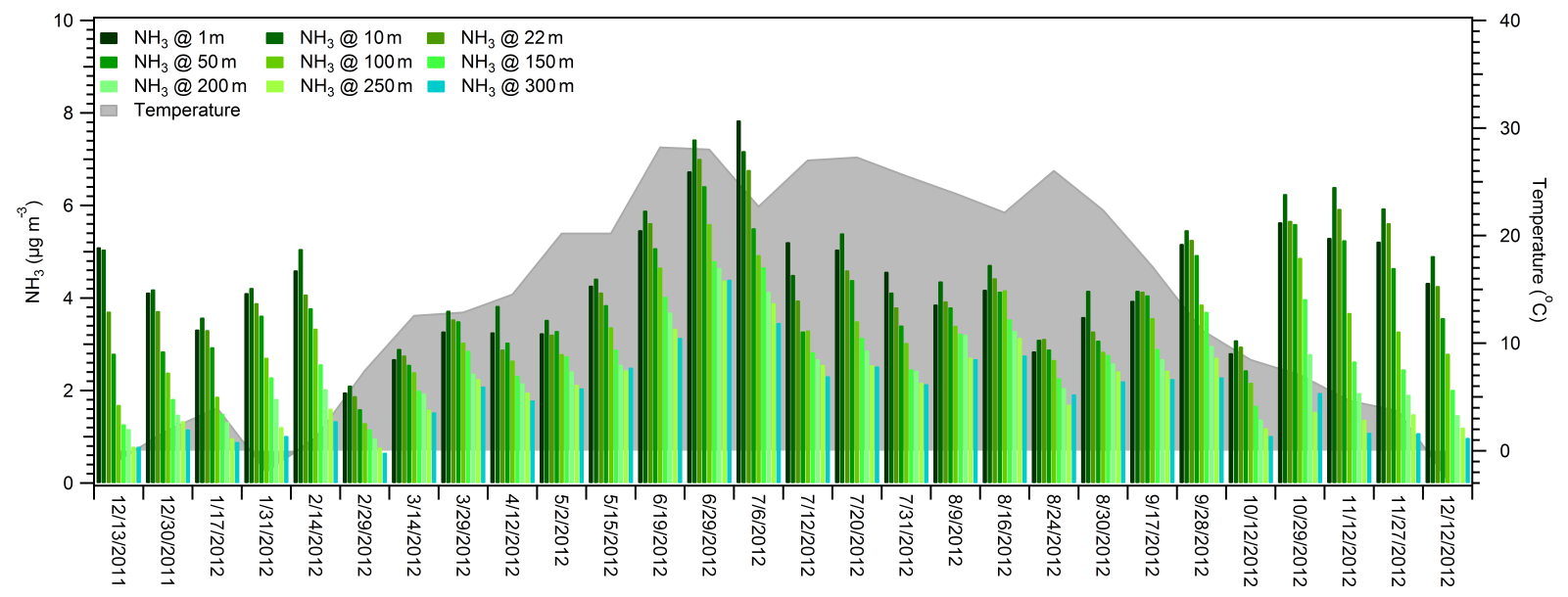

Figure 4. Time series of vertical distribution of $\mathrm{NH}_{3}$ concentrations and surface temperature measured at the BAO tower from $13 \mathrm{December}$ 2011 to 9 January 2013.
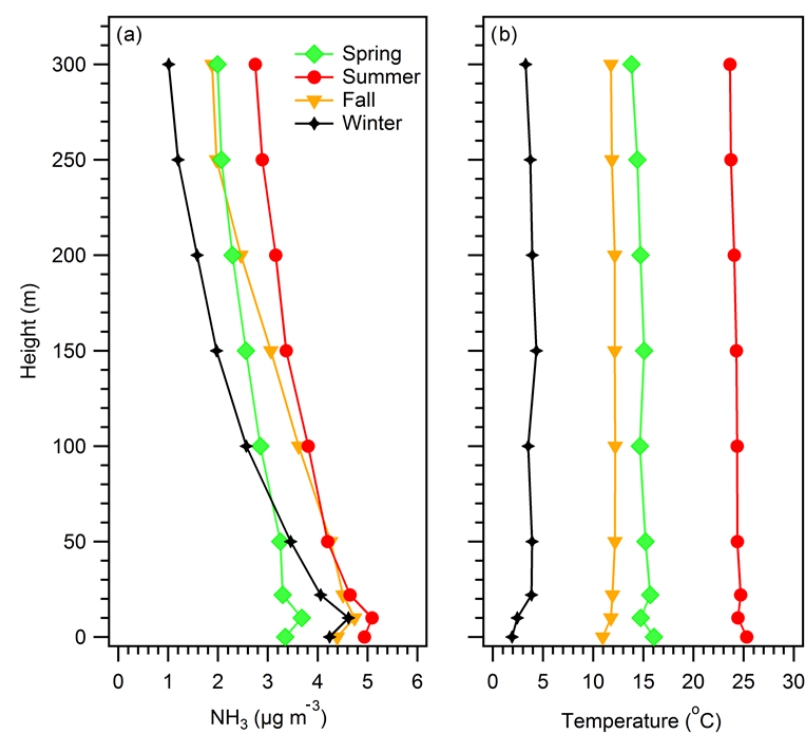

Figure 5. Comparison of seasonal average vertical profiles of (a) $\mathrm{NH}_{3}$ concentration and (b) temperature measured at the BAO tower from 13 December 2011 to 9 January 2013.

spring; June, July, and August as summer; September, October, and November as fall; and December, January, and February as winter. Vertical concentration differences were greatest in winter (from an average concentration greater than $4 \mu \mathrm{g} \mathrm{m}^{-3}$ near the surface to approximately $1 \mu \mathrm{g} \mathrm{m}^{-3}$ at $300 \mathrm{~m}$, representing a decrease of approximately $75 \%$ ) followed by fall $\left(1.9 \mu \mathrm{g} \mathrm{m}^{-3}\right.$ near the surface and $4.5 \mu \mathrm{g} \mathrm{m}^{-3}$ at $300 \mathrm{~m}$ ). Low-level temperature inversions which trap emissions closer to the surface are common in both seasons (fall and winter). The highest concentrations across the profile were observed in summer, when volatility of $\mathrm{NH}_{3}$ increases due to higher temperatures and vertical mixing is enhanced. The concentration decrease from the surface to $300 \mathrm{~m}$ aver- aged only $44 \%$ in summer. Increased $\mathrm{NH}_{3}$ concentrations in summer also may reflect a shift in thermodynamic equilibrium of particulate $\mathrm{NH}_{4} \mathrm{NO}_{3}$ toward its gas-phase precursors $\mathrm{NH}_{3}$ and $\mathrm{HNO}_{3}$. Previous studies have reported increased $\mathrm{NH}_{3}$ concentrations in summer and/or reduced concentrations in winter due to the seasonal changes of $\mathrm{NH}_{3}$ emissions and gas-particle partitioning ( $\mathrm{Li}$ et al., 2014; Meng et al., 2011; Plessow et al., 2005; Walker et al., 2004; Zbieranowski and Aherne, 2012). Day et al. (2012) previously suggested that trapping of regional $\mathrm{NH}_{3}$ emissions in a shallow winter boundary layer can produce elevated surface concentrations. The BAO tower observations in Fig. 5a support this hypothesis, as concentrations are elevated near the surface but fall off quickly at heights greater than $10-20 \mathrm{~m}$. Evidence of winter temperature inversions is present even in the average winter temperature profile shown in Fig. $5 b$.

Several long-term measurements have shown a strong correlation between $\mathrm{NH}_{3}$ concentration and ambient temperature, due to enhanced $\mathrm{NH}_{3}$ emissions from soil and volatilization from $\mathrm{NH}_{4} \mathrm{NO}_{3}$ particulate matter (Bari et al., 2003; Ianniello et al., 2010; Lin et al., 2006; Meng et al., 2011). Almost no correlation $\left(R^{2}=0.02\right)$ between $\mathrm{NH}_{3}$ concentration and temperature was observed at $1 \mathrm{~m}$ height in the current study; higher correlation $\left(R^{2}=0.65\right)$ was found at the top of the tower (Fig. S3a). The correlation coefficients increase substantially with height (Fig. S3b), particularly above $50 \mathrm{~m}$, suggesting that temperature might influence ambient $\mathrm{NH}_{3}$ concentrations at this location at higher altitude but is not a dominant factor at the surface (Fig. S3b). This pattern likely reflects greater vertical mixing during warmer periods, as discussed above. In order to investigate the possible influence of changes in $\mathrm{NH}_{4} \mathrm{NO}_{3}$ aerosol-gas partitioning on vertical $\mathrm{NH}_{3}$ concentration profiles, thermodynamic simulations were performed using the ISORROPIA II model (Fountoukis and Nenes, 2007; Fig. S4). Model inputs in- 
(a)

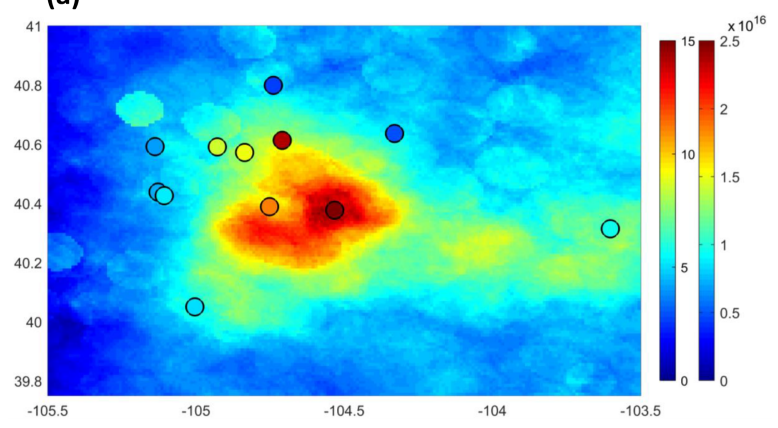

(b)

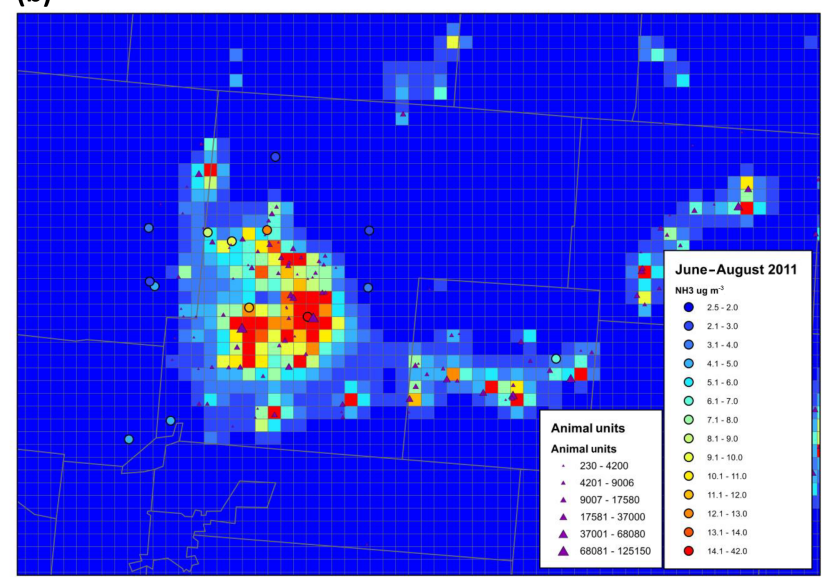

Figure 6. Comparison of surface $\mathrm{NH}_{3}$ concentrations with IASI satellite retrievals and CAMx model simulations. (a) Radiello passive sampler surface $\mathrm{NH}_{3}$ concentrations $\left(\mu \mathrm{g} \mathrm{m}^{-3}\right.$, left color bar) plotted on top of IASI-NH $\mathrm{NH}_{3}$ satellite column retrievals (molec. $\mathrm{cm}^{-2}$, right color bar), both averaged for the summers of 4 years (2012-2015). The BAO site was only sampled in situ in the summer of 2012. (b) Comparison of measured and modeled $\mathrm{NH}_{3}$ concentrations in the summer of 2011. The circles correspond to concentrations measured; these are superimposed on the CAMx modeled $\mathrm{NH}_{3}$ concentration field. Animal units are indicated by the triangles.

cluded BAO site URG denuder/filter-pack surface measurements of key species (gaseous $\mathrm{NH}_{3}$ and $\mathrm{HNO}_{3}$ and $\mathrm{PM}_{2.5}$ $\mathrm{NH}_{4}^{+}, \mathrm{NO}_{3}^{-}$, and $\mathrm{SO}_{4}^{2-}$ ) and measurements of temperature and relative humidity at each tower measurement height. Because vertical differences in temperature and relative humidity were generally small, little change was predicted with height in the thermodynamic partitioning of the $\mathrm{NH}_{3}-\mathrm{HNO}_{3}$ $\mathrm{NH}_{4} \mathrm{NO}_{3}$ system. Consequently, a shift in partitioning toward the particle phase as temperatures cool at higher altitudes appears not to account for much of the observed decrease in $\mathrm{NH}_{3}$ concentration with height. For this location and for the lowest $300 \mathrm{~m}$ of the atmosphere, the vertical thermal structure of the atmosphere and associated mixing, ambient dilution, and $\mathrm{NH}_{3}$ surface deposition appear to be the major factors determining vertical distributions of atmospheric $\mathrm{NH}_{3}$.

\subsection{Comparison with satellite observations}

Several recent studies have used surface $\mathrm{NH}_{3}$ measurements to evaluate or improve remote sensing techniques for retrieving $\mathrm{NH}_{3}$ concentrations and determining distributions (Heald et al., 2012; Pinder et al., 2011; Zhu et al., 2013; Van Damme et al., 2015). The first version of the IASI-NH $\mathrm{NH}_{3}$ data set has been evaluated against model simulations over Europe and has demonstrated consistency between model output and satellite-retrieval-derived $\mathrm{NH}_{3}$ concentrations (Van Damme et al., 2014). These initial validation steps highlighted the need to expand the $\mathrm{NH}_{3}$ monitoring network to achieve a more complete validation of the $\mathrm{NH}_{3}$ satellite observations (Van Damme et al., 2015). The comparison here is a contribution to that effort and benefits from a relatively high spatial density of monitoring sites in a region with substantial $\mathrm{NH}_{3}$ emission and concentration gradients.

In Fig. 6a IASI-retrieved column distributions averaged over the ground-based measurement period from 2012 to 2015 are compared with the Radiello passive $\mathrm{NH}_{3}$ surface concentration measurements in northeastern Colorado. Only IASI observations with a relative error below $100 \%$ or an absolute error below $5 \times 10^{15}$ molec., $\mathrm{cm}^{-2}$ were used for comparison in the latitude range from 39 to $42^{\circ} \mathrm{N}$ and longitude range from 102 to $106^{\circ} \mathrm{W}$. This combined filtering using relative and absolute thresholds on the error avoids introducing a bias when averaging and results in considering $98.5 \%$ of the IASI cloud-free morning observations for this area. Overall, the IASI observations and Radiello passive measurements show similar spatial patterns. The IASI columns exceed $2 \times 10^{16}$ molec. $\mathrm{cm}^{-2}$ around the KY site and decrease moving away from concentrated agricultural areas.

In order to further explore the temporal concentration variability, including the postulated contributions from wildfire to local ambient $\mathrm{NH}_{3}$ concentrations, averages of IASI measurements (based on weekly or biweekly Radiello passive sampling periods) above the FC_W site are shown in Fig. 7. In general, similar temporal trends are found between the Radiello passive measurements (blue) and IASI observations (red). Elevated $\mathrm{NH}_{3}$ concentrations during the High Park Fire period in June 2012 are seen in both the satellite and surface measurements. It is also interesting to note the relatively high IASI-NH $\mathrm{N}_{3}$ total column measured at the beginning of June $2011\left(8.5 \times 10^{15}\right.$ molec. $\left.\mathrm{cm}^{-2}\right)$, which could be linked with transported wildfire plumes at higher altitude (Fig. S5) not captured by surface measurements.

The similar spatial and temporal patterns captured show the respective consistency of the IASI measurements and the Radiello network to monitor regional $\mathrm{NH}_{3}$ variations in northeast Colorado. The passive measurements provide an accurate, long-term record of spatial variability and surface concentration trends, while the IASI satellite $\mathrm{NH}_{3}$ columns provide higher time resolution snapshots of conditions over the region, including plumes elevated above the surface. 


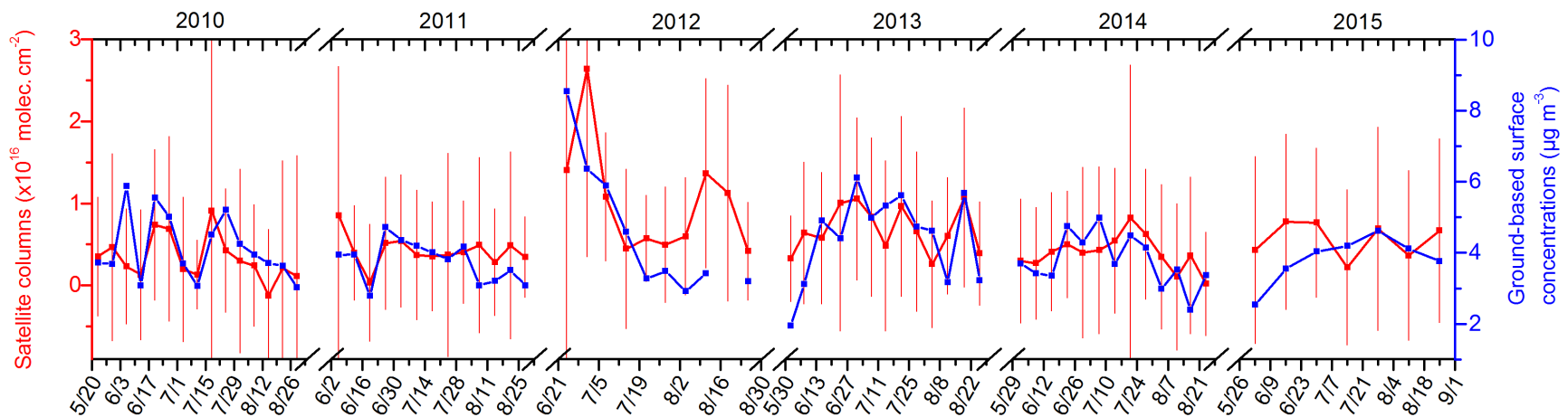

Figure 7. Time series of (bi)weekly averaged IASI-NH 3 satellite column (red, $\times 10^{16}$ molec. $\mathrm{cm}^{-2}$ ) and surface concentrations measured by Radiello passive sampler (blue, $\mu \mathrm{g} \mathrm{m}^{-3}$ ) at FC_W site. The error bars represent the standard deviation of the mean satellite column retrievals.

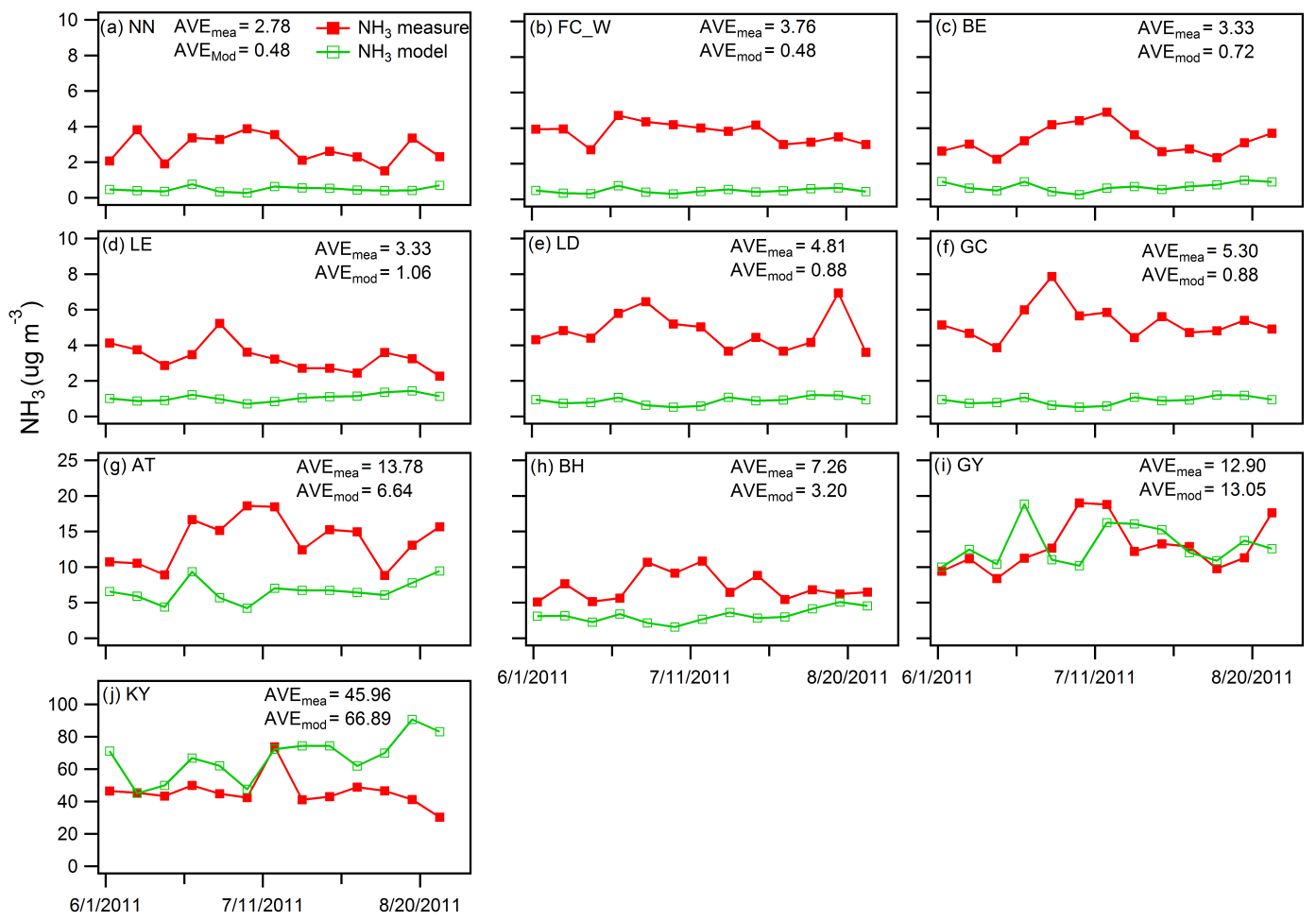

Figure 8. Time series of weekly $\mathrm{NH}_{3}$ concentrations measured (red) and modeled (green) in the summer of 2011 (2 June-31 August 2011 ) at all the sites.

\subsection{Comparison with CAMx model simulations}

Simulations with CAMx version 6.1 were performed with two-way nested domains and horizontal grid size resolutions of 36, 12, and $4 \mathrm{~km}$ (Fig. S6). The outermost domain includes the continental US, southern Canada, and northern Mexico; the $12 \mathrm{~km}$ domain extends over the western states; and the $4 \mathrm{~km}$ domain extends over Colorado, Wyoming, and Utah. The Weather Research and Forecasting Model (WRF), Advanced Research WRF (ARW) v3.5.1, was used to develop meteorological inputs to the air quality model (Skamarock et al., 2005). The input meteorological data represent conditions as they occurred in 2011. A performance evaluation of the WRF simulations was conducted by The University of North Carolina at Chapel Hill (ThreeState Air Quality Modeling Study (3SAQS) - Weather Research Forecast 2011 Meteorological Model Application/Evaluation available at: http://vibe.cira.colostate.edu). Model performance was evaluated by the Intermountain West Data Warehouse team (Adelman et al., 2015). The model met performance standards as recommended by the US EPA for regulatory photochemical modeling purposes (https://www3.epa.gov/scram001/guidance/guide). In general, model performance statistics for ambient concentrations 

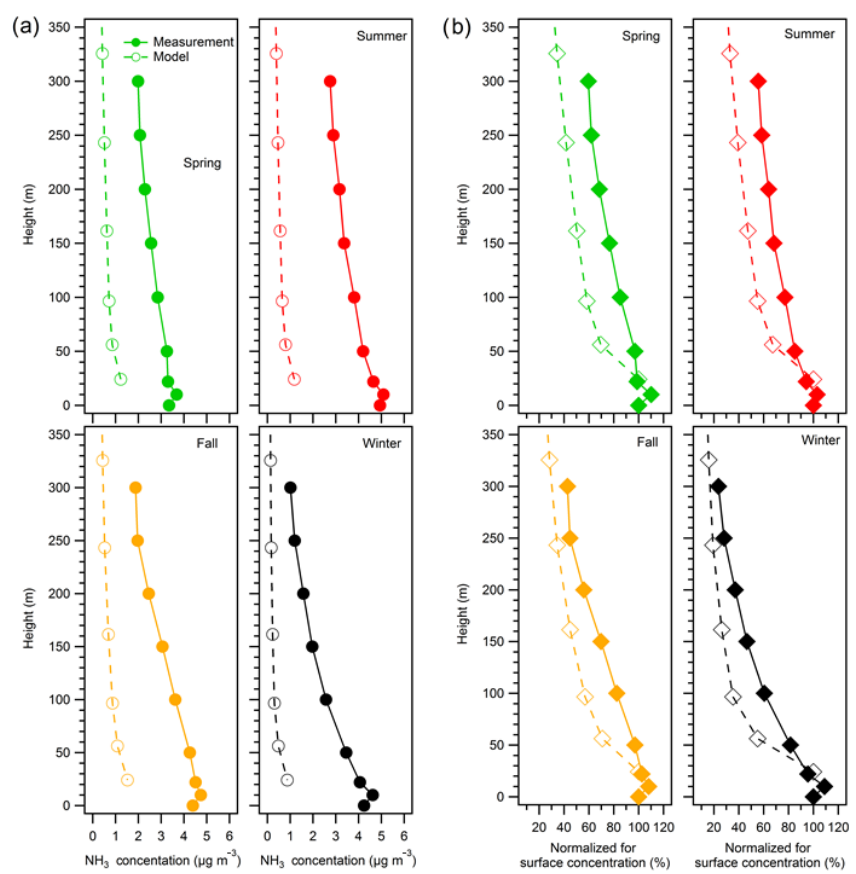

Figure 9. (a) Comparison of seasonal $2012 \mathrm{NH}_{3}$ concentrations $\left(\mu \mathrm{g} \mathrm{m}^{-3}\right)$ : passive measurements (solid lines) and $2011 \mathrm{CAMx}$ modeling results (dashed lines); (b) comparison of seasonal $\mathrm{NH}_{3}$ passive measurements normalized by surface concentrations (solid lines) and CAMx modeling results (dashed lines). Each profile is normalized such that the concentration at the lowest level is set to 100.

of ozone and many individual species of fine particles fell within the recommended ranges. However, concentrations of organic and elemental carbon (two particulate matter species) are overpredicted by the model and performance criteria fall outside the recommended range. Additionally, modeled particulate $\mathrm{NO}_{3}^{-}$concentrations are overpredicted in the winter, and underpredicted in the summer in most locations. Model performance with respect to $\mathrm{NH}_{3}$ can be best evaluated using the measurement data presented in this report.

The Sparse Matrix Operator Kernel Emissions (SMOKE) processing system (https://www.cmascenter.org/smoke/ documentation $/ 3.1 / \mathrm{html} /$; Houyoux et al., 2000) was used to prepare the emissions inventory data in a format that reflects the spatial, temporal, and chemical speciation parameters required by CAMx. The emissions inventory is based on the 2011 NEI v1 (http://www.epa.gov/ttn/chief/net/2011). Important updates to the $2011 \mathrm{NEI}$ included a detailed oil and gas inventory, and the spatial allocation of livestock emissions using latitude/longitude location data of livestock facilities (IWDW; Adelman et al., 2015). Boundary conditions were developed using the Model for Ozone and Related chemical Tracers (MOZART) and represent the 2011 modeling period (Emmons et al., 2010).

Figure $6 \mathrm{~b}$ illustrates an evaluation of CAMx simulated $\mathrm{NH}_{3}$ concentrations both spatially and across time. Gen- erally speaking, CAMx reasonably reproduces average observed $\mathrm{NH}_{3}$ in the northeastern plains of Colorado, with a model / measurement ratio of $91 \%$ averaged across all measurement locations. This is a much closer match than a separate $12 \mathrm{~km}$ resolution CMAQ summer 2014 model comparison to surface passive ammonia measurements (including some of the observations collected in the current study) reported by Battye et al. (2016), who found that the average measured concentration was 2.7 times higher than the modeled concentration. Despite the better average comparison of measurements with the CAMx prediction reported here, however, the CAMx simulation tends to overestimate concentrations near major $\mathrm{NH}_{3}$ sources (e.g., at the $\mathrm{KY}$ monitoring site), while underestimating $\mathrm{NH}_{3}$ concentrations at sites further away from feedlot locations (Fig. 8). Across our measurement locations, the model performance is best at GY, a site surrounded by, but not immediately adjacent to, large $\mathrm{NH}_{3}$ sources. The modest overestimation of $\mathrm{NH}_{3}$ concentration at the KY site is likely an artifact of model resolution and the assumption that emissions are immediately and homogeneously dispersed throughout the grid cell in which they are emitted. A model-measurement mismatch moving farther away from $\mathrm{NH}_{3}$ source locations could result from a number of factors, including smaller and/or non-agricultural sources (e.g., suburban $\mathrm{N}$ fertilization or transportation) underrepresented in the emissions inventory, possible overestimation of $\mathrm{NH}_{3}$ deposition in the model, which does not account for the bidirectional nature of $\mathrm{NH}_{3}$ exchange with the surface, or a tendency for the model to more actively move surface $\mathrm{NH}_{3}$ emissions aloft during downwind transport than occurs in the real atmosphere.

Figure 9 shows both measured (measurements taken in 2012) and modeled (2011) vertical concentrations of $\mathrm{NH}_{3}$ at the BAO tower location. Although these comparisons are for two adjacent years, the results presented earlier demonstrate that seasonal average concentrations across the region are typically similar from year to year. Modeled vertical $\mathrm{NH}_{3}$ concentrations are reported from the lowest 6 levels of the model, up to approximately $325 \mathrm{~m}$ above the surface. The model height represented by the value plotted on the $y$ axis in Fig. 9a represents the top of the layer from which the corresponding concentration is reported (i.e., the surface or lowest model layer is reported at $24 \mathrm{~m}$ - the approximate height of the surface layer). Model layer height is based on the meteorological model and modeled pressure and is not fixed (http://vibe.cira.colostate.edu/wiki/Attachments/ Modeling/3SAQS_2011_WRF_MPE_v05Mar2015.pdf).

The vertical concentrations are homogeneous within each model layer. Therefore, the model is not able to capture the detailed vertical pattern shown from 0 to 10 to $20 \mathrm{~m}$ by the observations. The model-measurement comparisons of vertical profiles demonstrate a significant underprediction by the model at all elevations in all four seasons. The underprediction at the surface is consistent with the observation above that the model tends to underestimate 
$\mathrm{NH}_{3}$ concentrations farther from the major regional feedlot sources. The fact that the model also underpredicts $\mathrm{NH}_{3}$ aloft suggests that the surface mismatch is not simply a result of excess vertical transport of $\mathrm{NH}_{3}$ in the model. Model vertical $\mathrm{NH}_{3}$ concentration profiles normalized for surface concentration are shown in Fig. 9b and compared to similarly normalized measurements. These profiles suggest that the model does a reasonable job of capturing the shape of the observed vertical concentration gradient, although the relative concentration decrease with height in the model is a bit stronger than observed via passive sampler measurements in each season.

\section{Conclusions}

Six years of passive sampler measurements revealed strong spatial differences in $\mathrm{NH}_{3}$ concentrations in northeastern Colorado. Summer average weekly $\mathrm{NH}_{3}$ concentrations ranged from 2.7 to $42.7 \mu \mathrm{g} \mathrm{m}^{-3}$. The lowest average $\mathrm{NH}_{3}$ concentration always occurred at a remote prairie site, while average $\mathrm{NH}_{3}$ concentrations nearly a factor of 15 greater were observed at a site near a large animal feeding operation. Based on 6 years of available data, no significant regional long-term trends were detected in $\mathrm{NH}_{3}$ concentrations at six of the nine study sites, consistent with similar seasonal meteorological conditions and relative stability in regional livestock head counts over the period. Two sites near animal feeding operations (GY and KY) showed evidence of an increasing $\mathrm{NH}_{3}$ concentration trend, while a decreasing trend was evident at a third site (BH). Further effort is warranted to see whether changes in local animal feeding operations might explain these trends. The $\mathrm{NH}_{3}$ concentration levels observed in this study provide an important reference point for evaluating the success of future efforts to mitigate regional $\mathrm{NH}_{3}$ emissions through voluntary implementation of BMPs as part of a strategy to reduce nitrogen deposition levels and impacts in nearby Rocky Mountain National Park.

Measurements of $\mathrm{NH}_{3}$ at the BAO meteorological tower near Erie, Colorado, provide the first long-term insights into vertical gradients of $\mathrm{NH}_{3}$ concentrations in the region and some of the first long-term measurements of this type anywhere in the world. A general pattern of decreasing $\mathrm{NH}_{3}$ concentrations with height above $10 \mathrm{~m}$ was observed in all seasons, as was a decreasing concentration below $10 \mathrm{~m}$ height. The lowest average concentrations were observed in winter at the surface along with a steeper vertical concentration gradient. Higher average concentrations were observed in summer at all altitudes along with a shallower vertical concentration gradient. Surface deposition, vertical dilution, and the formation of thermal inversions that limit the vertical mixing of regional, surface-based $\mathrm{NH}_{3}$ emissions appear to have greater influence than temperature and humidity-driven changes in $\mathrm{NH}_{4} \mathrm{NO}_{3}$ gas-particle partitioning on the observed vertical concentration profiles.
Comparison of measured $\mathrm{NH}_{3}$ spatial distributions with IASI satellite-retrieved $\mathrm{NH}_{3}$ columns reveals that both monitoring techniques capture similar spatial and temporal variability in northeastern Colorado. These comparisons lend additional weight to the growing body of evidence suggesting that satellite retrievals of $\mathrm{NH}_{3}$ columns can provide useful information about spatial and temporal concentration variability of this key species, even in regions with strong sources and sharp spatial concentration gradients. Some temporal differences between satellite and in situ measurements at the FC_W site appear to reflect $\mathrm{NH}_{3}$ in elevated wildfire plumes that are observed from the satellite but are not sampled at the surface.

Measured spatial distributions of $\mathrm{NH}_{3}$ concentrations also provide a good basis for comparison to regional air quality model simulations. A comparison with CAMx simulations finds that the model captures average $\mathrm{NH}_{3}$ concentrations across the study, but tends to overpredict concentrations close to sources and underpredict concentrations at locations further away. A comparison of measured and modeled vertical profiles in a non-source region reveals an underprediction of modeled $\mathrm{NH}_{3}$ from the surface up to $300 \mathrm{~m}$ in all seasons. The mismatch aloft provides evidence that the difficulty for the model in reproducing surface observations away from sources is not a simple result of excess vertical mixing of $\mathrm{NH}_{3}$ emissions in the model. Rather, the model emission inventory may be missing or underpredicting smaller or nonagricultural $\mathrm{NH}_{3}$ sources or, perhaps more likely, the model may be overpredicting surface $\mathrm{NH}_{3}$ deposition due to the absence of bidirectional treatment of $\mathrm{NH}_{3}$ atmosphere-surface exchange. Although additional research is definitely needed, we expect the $\mathrm{NH}_{3}$ concentrations and spatial/vertical differences presented here to be useful in constraining future simulated concentrations of atmospheric $\mathrm{NH}_{3}$ in chemical transport models.

Data availability. All data sets related to this paper have been deposited in a repository operated by Colorado State University (http://hdl.handle.net/10217/180229; they can also be obtained by contacting the principal investigator, J. L. Collett Jr. (collett@atmos.colostate.edu).

\section{The Supplement related to this article is available online at doi:10.5194/acp-17-6197-2017-supplement.}

Competing interests. The authors declare that they have no conflict of interest.

Acknowledgements. Primary funding for this work was provided by the USDA through the Colorado State University Agriculture Experiment Station (project COL00699). Additional support and equipment were provided by the National Park Service. The authors 
are grateful to the many people who helped to make these measurements possible, especially allowing access to the sampling sites. The authors thank Bonne Ford, Arsineh Hecobian, and Liye Zhu from Colorado State University for their helpful suggestions. The authors thank Daniel Wolfe and Bruce Bartram from the BAO tower for assistance with the tower measurements. The authors also thank Tom Moore from Western States Air Resources Council and Rodger Ames from Cooperative Institute for Research in the Atmosphere for modeling help. Simon Whitburn is grateful for his $\mathrm{PhD}$ grant (Boursier FRIA) to the "Fonds pour la Formation à la Recherche dans l'Industrie et dans l'Agriculture" of Belgium. Lieven Clarisse is a Research Associate (Chercheur Qualifié) with the Belgian F.R.S.-FNRS.

Edited by: S. Brown

Reviewed by: two anonymous referees

\section{References}

Adelman, Z., Shanker, U., Yang, D., and Morris, R.: Three-State Air Quality Modeling Study CAMx Photochemical Grid Model Draft Model Performance Evaluation Simulation Year 2011, University of North Carolina at Chapel Hill and ENVIRON International Corporation, Novato, CA, June, 2015.

Aneja, V. P., Roelle, P. A., Murray, G. C., Southerland, J., Erisman, J. W., Fowler, D., Asman, W. A. H., and Patni, N.: Atmospheric nitrogen compounds II: emissions, transport, transformation, deposition and assessment, Atmos. Environ., 35, 1903-1911, 2001.

Aneja, V. P., Schlesinger, W. H., Nyogi, D., Jennings, G., Gilliam, W., Knighton, R. E., Duke, C. S., Blunden, J., and Krishnan, S.: Emerging national research needs for agricultural air quality, Eos, Transactions American Geophysical Union, 87, 25-29, 2006.

Asman, W. A. H., Sutton, M. A., and SchjØRring, J. K.: Ammonia: emission, atmospheric transport and deposition, New Phytol., 139, 27-48, 1998.

Bari, A., Ferraro, V., Wilson, L. R., Luttinger, D., and Husain, L.: Measurements of gaseous $\mathrm{HONO}, \mathrm{HNO}_{3}, \mathrm{SO}_{2}, \mathrm{HCl}, \mathrm{NH}_{3}$, particulate sulfate and $\mathrm{PM}_{2.5}$ in New York, NY, Atmos. Environ., 37, 2825-2835, 2003.

Bash, J. O., Cooter, E. J., Dennis, R. L., Walker, J. T., and Pleim, J. E.: Evaluation of a regional air-quality model with bidirectional $\mathrm{NH}_{3}$ exchange coupled to an agroecosystem model, Biogeosciences, 10, 1635-1645, doi:10.5194/bg-10-1635-2013, 2013.

Battye, W. H., Bray, C. D., Aneja, V. P., Tong, D., Lee, P., and Tang, Y.: Evaluating ammonia $\left(\mathrm{NH}_{3}\right)$ predictions in the NOAA National Air Quality Forecast Capability (NAQFC) using in situ aircraft, ground-level, and satellite measurements from the DISCOVER-AQ Colorado campaign, Atmos. Environ., 140, 342-351, 2016.

Bauer, S. E., Tsigaridis, K., and Miller, R.: Significant atmospheric aerosol pollution caused by world food cultivation, Geophys. Res. Lett., 43, 5394-5400, 2016.

Beem, K. B., Raja, S., Schwandner, F. M., Taylor, C., Lee, T., Sullivan, A. P., Carrico, C. M., McMeeking, G. R., Day, D., and Levin, E.: Deposition of reactive nitrogen during the Rocky Mountain Airborne Nitrogen and Sulfur (RoMANS) study, Environ. Pollut., 158, 862-872, 2010.
Benedict, K. B., Carrico, C. M., Kreidenweis, S. M., Schichtel, B., Malm, W. C., and Collett, J. L.: A seasonal nitrogen deposition budget for Rocky Mountain National Park, Ecol. Appl., 23, 1156-1169, 2013a.

Benedict, K. B., Chen, X., Sullivan, A. P., Li, Y., Day, D., Prenni, A. J., Levin, E., Kreidenweis, S. M., Malm, W. C., and Schichtel, B. A.: Atmospheric concentrations and deposition of reactive nitrogen in Grand Teton National Park, J. Geophys. Res.-Atmos., 118, 11875-811887, 2013b.

Benedict, K. B., Day, D., Schwandner, F. M., Kreidenweis, S. M., Schichtel, B., Malm, W. C., and Collett, J. L.: Observations of atmospheric reactive nitrogen species in Rocky Mountain National Park and across northern Colorado, Atmos. Environ., 64, 66-76, 2013c.

Benedict, K. B., Prenni, A. J., Carrico, C. M., Sullivan, A. P., Schichtel, B. A., and Collett Jr., J. L.: Enhanced concentrations of reactive nitrogen species in wildfire smoke, Atmos. Environ., 148, 8-15, 2017.

Chang, Y., Zou, Z., Deng, C., Huang, K., Collett, J. L., Lin, J., and Zhuang, G.: The importance of vehicle emissions as a source of atmospheric ammonia in the megacity of Shanghai, Atmos. Chem. Phys., 16, 3577-3594, doi:10.5194/acp-16-3577-2016, 2016.

Cisneros, R., Bytnerowicz, A., Schweizer, D., Zhong, S., Traina, S., and Bennett, D. H.: Ozone, nitric acid, and ammonia air pollution is unhealthy for people and ecosystems in southern Sierra Nevada, California, Environ. Pollut., 158, 3261-3271, 2010.

Clarisse, L., R'Honi, Y., Coheur, P.-F., Hurtmans, D., and Clerbaux, C.: Thermal infrared nadir observations of 24 atmospheric gases, Geophys. Res. Lett., 38, L10802, doi:10.1029/2011GL047271, 2011.

Clerbaux, C., Boynard, A., Clarisse, L., George, M., Hadji-Lazaro, J., Herbin, H., Hurtmans, D., Pommier, M., Razavi, A., Turquety, S., Wespes, C., and Coheur, P.-F.: Monitoring of atmospheric composition using the thermal infrared IASI/MetOp sounder, Atmos. Chem. Phys., 9, 6041-6054, doi:10.5194/acp-9-6041-2009, 2009.

Coheur, P.-F., Clarisse, L., Turquety, S., Hurtmans, D., and Clerbaux, C.: IASI measurements of reactive trace species in biomass burning plumes, Atmos. Chem. Phys., 9, 5655-5667, doi:10.5194/acp-9-5655-2009, 2009.

Davidson, C. I., Phalen, R. F., and Solomon, P. A.: Airborne Particulate Matter and Human Health: A Review, Aerosol Sci. Technol., 39, 737-749, 2005.

Day, D. E., Chen, X., Gebhart, K. A., Carrico, C. M., Schwandner, F. M., Benedict, K. B., Schichtel, B. A., and Collett, J. L.: Spatial and temporal variability of ammonia and other inorganic aerosol species, Atmos. Environ., 61, 490-498, 2012.

Eilerman, S. J., Peischl, J., Neuman, J. A., Ryerson, T. B., Aikin, K. C., Holloway, M. W., Zondlo, M. A., Golston, L. M., Pan, D., Floerchinger, C., and Herndon, S. C.: Characterization of ammonia, methane, and nitrous oxide emissions from concentrated animal feeding operations in northeastern Colorado, Environ. Sci Tech., 50, 10885-10893, doi:10.1021/acs.est.6b02851, 2016.

Ellis, R. A., Jacob, D. J., Sulprizio, M. P., Zhang, L., Holmes, C. D., Schichtel, B. A., Blett, T., Porter, E., Pardo, L. H., and Lynch, J. A.: Present and future nitrogen deposition to national parks in the United States: critical load exceedances, Atmos. Chem. Phys., 13, 9083-9095, doi:10.5194/acp-13-9083-2013, 2013. 
Emmons, L. K., Walters, S., Hess, P. G., Lamarque, J.-F., Pfister, G. G., Fillmore, D., Granier, C., Guenther, A., Kinnison, D., Laepple, T., Orlando, J., Tie, X., Tyndall, G., Wiedinmyer, C., Baughcum, S. L., and Kloster, S.: Description and evaluation of the Model for Ozone and Related chemical Tracers, version 4 (MOZART-4), Geosci. Model Dev., 3, 43-67, doi:10.5194/gmd3-43-2010, 2010

EPA, U.: Air Quality Modeling Final Rule Technical Support Document, EPA Office of Air Quality Planning and Standards, 2011.

Fountoukis, C. and Nenes, A.: ISORROPIA II: a computationally efficient thermodynamic equilibrium model for $\mathrm{K}^{+}-\mathrm{Ca}^{2+}$ $\mathrm{Mg}^{2+}-\mathrm{NH}_{4}^{+}-\mathrm{Na}^{+}-\mathrm{SO}_{4}^{2-}-\mathrm{NO}_{3}^{-}-\mathrm{Cl}^{-}-\mathrm{H}_{2} \mathrm{O}$ aerosols, Atmospheric Chemistry and Physics, 7, 4639-4659, doi:10.5194/acp7-4639-2007, 2007.

Fowler, D., Pitcairn, C. E. R., Sutton, M. A., Flechard, C., Loubet, B., Coyle, M., and Munro, R. C.: The mass budget of atmospheric ammonia in woodland within $1 \mathrm{~km}$ of livestock buildings, Environ. Pollut., 102, 343-348, 1998.

Gilbert, R. O.: Statistical methods for environmental pollution monitoring, John Wiley \& Sons, 1987.

Hand, J. L., Schichtel, B. A., Malm, W. C., and Pitchford, M. L.: Particulate sulfate ion concentration and $\mathrm{SO}_{2}$ emission trends in the United States from the early 1990s through 2010, Atmos. Chem. Phys., 12, 10353-10365, doi:10.5194/acp-1210353-2012, 2012

Heald, C. L., Collett Jr., J. L., Lee, T., Benedict, K. B., Schwandner, F. M., Li, Y., Clarisse, L., Hurtmans, D. R., Van Damme, M., Clerbaux, C., Coheur, P.-F., Philip, S., Martin, R. V., and Pye, H. O. T.: Atmospheric ammonia and particulate inorganic nitrogen over the United States, Atmos. Chem. Phys., 12, 10295-10312, doi:10.5194/acp-12-10295-2012, 2012.

Hertel, O., Skjøth, C. A., Løfstrøm, P., Geels, C., Frohn, L. M., Ellermann, T., and Madsen, P. V.: Modelling Nitrogen Deposition on a Local Scale - A Review of the Current State of the Art, Environ. Chem., 3, 317-337, 2006.

Horii, C. V., William Munger, J., Wofsy, S. C., Zahniser, M., Nelson, D., and Barry McManus, J.: Atmospheric reactive nitrogen concentration and flux budgets at a Northeastern US forest site, Agr. Forest Meteorol., 136, 159-174, 2006.

Houyoux, M., Vukovich, J., Brandmeyer, J., Seppanen, C., and Holland, A.: Sparse Matrix Operator Kernel Emissions Modeling System-SMOKE User Manual, Prepared by MCNC-North Carolina Supercomputing Center, Environmental Programs, Research Triangle Park, NC, 2000.

Ianniello, A., Spataro, F., Esposito, G., Allegrini, I., Rantica, E., Ancora, M. P., Hu, M., and Zhu, T.: Occurrence of gas phase ammonia in the area of Beijing (China), Atmos. Chem. Phys., 10, 9487-9503, doi:10.5194/acp-10-9487-2010, 2010.

Ianniello, A., Spataro, F., Esposito, G., Allegrini, I., Hu, M., and Zhu, T.: Chemical characteristics of inorganic ammonium salts in $\mathrm{PM}_{2.5}$ in the atmosphere of Beijing (China), Atmos. Chem. Phys., 11, 10803-10822, doi:10.5194/acp-11-10803-2011, 2011.

Langridge, J. M., Lack, D., Brock, C. A., Bahreini, R., Middlebrook, A. M., Neuman, J. A., Nowak, J. B., Perring, A. E., Schwarz, J. P., Spackman, J. R., Holloway, J. S., Pollack, I. B., Ryerson, T. B., Roberts, J. M., Warneke, C., de Gouw, J. A., Trainer, M. K., and Murphy, D. M.: Evolution of aerosol properties impacting visibility and direct climate forcing in an ammonia-rich urban environment, J. Geophys. Res.-Atmos., 117, D00V11, doi:10.1029/2011JD017116, 2012.

Lee, T., Yu, X.-Y., Kreidenweis, S. M., Malm, W. C., and Collett, J. L.: Semi-continuous measurement of $\mathrm{PM}_{2.5}$ ionic composition at several rural locations in the United States, Atmos. Environ., 42, 6655-6669, 2008.

Lelieveld, J., Evans, J. S., Fnais, M., Giannadaki, D., and Pozzer, A.: The contribution of outdoor air pollution sources to premature mortality on a global scale, Nature, 525, 367-371, 2015.

Li, Y., Schwandner, F. M., Sewell, H. J., Zivkovich, A., Tigges, M., Raja, S., Holcomb, S., Molenar, J. V., Sherman, L., Archuleta, C., Lee, T., and Collett Jr., J. L.: Observations of ammonia, nitric acid, and fine particles in a rural gas production region, Atmos. Environ., 83, 80-89, 2014.

Li, Y., Schichtel, B. A., Walker, J. T., Schwede, D. B., Chen, X., Lehmann, C. M. B., Puchalski, M. A., Gay, D. A., and Collett, J. L.: Increasing importance of deposition of reduced nitrogen in the United States, P. Natl. Acad. Sci. USA, 113, 5874-5879, 2016.

Lin, Y.-C., Cheng, M.-T., Ting, W.-Y., and Yeh, C.-R.: Characteristics of gaseous $\mathrm{HNO}_{2}, \mathrm{HNO}_{3}, \mathrm{NH}_{3}$ and particulate ammonium nitrate in an urban city of Central Taiwan, Atmos. Environ., 40, 4725-4733, 2006.

Luo, M., Shephard, M. W., Cady-Pereira, K. E., Henze, D. K., Zhu, L., Bash, J. O., Pinder, R. W., Capps, S. L., Walker, J. T., and Jones, M. R.: Satellite observations of tropospheric ammonia and carbon monoxide: Global distributions, regional correlations and comparisons to model simulations, Atmos. Environ., 106, 262277, 2015.

Malm, W. C., Schichtel, B. A., Barna, M. G., Gebhart, K. A., Rodriguez, M. A., Collett, J. L., Carrico, C. M., Benedict, K. B., Prenni, A. J., and Kreidenweis, S. M.: Aerosol species concentrations and source apportionment of ammonia at Rocky Mountain National Park, J. Air Waste Manage. Assoc., 63, 1245-1263, 2013.

Malm, W. C., Rodriguez, M. A., Schichtel, B. A., Gebhart, K. A., Thompson, T. M., Barna, M. G., Benedict, K. B., Carrico, C. M., and Collett, J. L.: A hybrid modeling approach for estimating reactive nitrogen deposition in Rocky Mountain National Park, Atmos. Environ., 126, 258-273, 2016.

Marchetto, A., Rogora, M., and Arisci, S.: Trend analysis of atmospheric deposition data: A comparison of statistical approaches, Atmos. Environ., 64, 95-102, 2013.

Massman, W. J.: A review of the molecular diffusivities of $\mathrm{H}_{2} \mathrm{O}$, $\mathrm{CO}_{2}, \mathrm{CH}_{4}, \mathrm{CO}, \mathrm{O}_{3}, \mathrm{SO}_{2}, \mathrm{NH}_{3}, \mathrm{~N}_{2} \mathrm{O}, \mathrm{NO}$, and $\mathrm{NO}_{2}$ in air, $\mathrm{O}_{2}$ and $\mathrm{N}_{2}$ near STP, Atmos. Environ., 32, 1111-1127, 1998.

Meng, Z. Y., Lin, W. L., Jiang, X. M., Yan, P., Wang, Y., Zhang, Y. M., Jia, X. F., and Yu, X. L.: Characteristics of atmospheric ammonia over Beijing, China, Atmos. Chem. Phys., 11, 61396151, doi:10.5194/acp-11-6139-2011, 2011.

Müller, M., Mikoviny, T., Feil, S., Haidacher, S., Hanel, G., Hartungen, E., Jordan, A., Märk, L., Mutschlechner, P., Schottkowsky, R., Sulzer, P., Crawford, J. H., and Wisthaler, A.: A compact PTR-ToF-MS instrument for airborne measurements of volatile organic compounds at high spatiotemporal resolution, Atmos. Meas. Tech., 7, 3763-3772, doi:10.5194/amt-7-37632014, 2014.

Nowak, J., Neuman, J., Bahreini, R., Middlebrook, A., Holloway, J., McKeen, S., Parrish, D., Ryerson, T., and Trainer, M.: Am- 
monia sources in the California South Coast Air Basin and their impact on ammonium nitrate formation, Geophys. Res. Lett., 39, L07804, doi:10.1029/2012GL05119, 2012.

Pan, Y. P., Wang, Y. S., Tang, G. Q., and Wu, D.: Wet and dry deposition of atmospheric nitrogen at ten sites in Northern China, Atmos. Chem. Phys., 12, 6515-6535, doi:10.5194/acp-12-65152012, 2012.

Park, R. J., Jacob, D. J., Kumar, N., and Yantosca, R. M.: Regional visibility statistics in the United States: Natural and transboundary pollution influences, and implications for the Regional Haze Rule, Atmos. Environ., 40, 5405-5423, 2006.

Parry, M. L., Canziani, O. F., Palutikof, J. P., van der Linden, P. J., and Hanson, C. E.: IPCC, 2007: climate change 2007: impacts, adaptation and vulnerability, Contribution of working group II to the fourth assessment report of the intergovernmental panel on climate change, in, Cambridge University Press, Cambridge, 2007.

Paulot, F., Jacob, D. J., and Henze, D. K.: Sources and processes contributing to nitrogen deposition: an adjoint model analysis applied to biodiversity hotspots worldwide, Environ. Sci. Tech., 47, 3226-3233, 2013.

Pinder, R. W., Walker, J. T., Bash, J. O., Cady-Pereira, K. E., Henze, D. K., Luo, M., Osterman, G. B., and Shephard, M. W.: Quantifying spatial and seasonal variability in atmospheric ammonia with in situ and space-based observations, Geophys. Res. Lett., 38, L04802, doi:10.1029/2010GL046146, 2011.

Pleim, J. E., Bash, J. O., Walker, J. T., and Cooter, E. J.: Development and evaluation of an ammonia bidirectional flux parameterization for air quality models, J. Geophys. Res.-Atmos., 118, 3794-3806, 2013.

Plessow, K., Spindler, G., Zimmermann, F., and Matschullat, J.: Seasonal variations and interactions of $\mathrm{N}$-containing gases and particles over a coniferous forest, Saxony, Germany, Atmos. Environ., 39, 6995-7007, 2005.

Prenni, A., Chen, X., Hecobian, A., Kreidenweis, S., Collett, J., and Schichtel, B.: Measurements of gas phase reactive nitrogen during two wildfires in Colorado, AGU Fall Meeting Abstracts, 0618, 2012.

Prenni, A., Levin, E., Benedict, K., Sullivan, A., Schurman, M., Gebhart, K., Day, D., Carrico, C., Malm, W., and Schichtel, B.: Gas-phase reactive nitrogen near Grand Teton National Park: Impacts of transport, anthropogenic emissions, and biomass burning, Atmos. Environ., 89, 749-756, 2014.

Puchalski, M. A., Sather, M. E., Walker, J. T., Lehmann, C. M., Gay, D. A., Mathew, J., and Robarge, W. P.: Passive ammonia monitoring in the United States: Comparing three different sampling devices, J. Environ. Monit., 13, 3156-3167, 2011.

Pul, A., Hertel, O., Geels, C., Dore, A., Vieno, M., Jaarsveld, H., Bergström, R., Schaap, M., and Fagerli, H.: Modelling of the Atmospheric Transport and Deposition of Ammonia at a National and Regional Scale, in: Atmospheric Ammonia, edited by: Sutton, M., Reis, S., and Baker, S. H., Springer Netherlands, 301358, 2009.

Reche, C., Viana, M., Pandolfi, M., Alastuey, A., Moreno, T., Amato, F., Ripoll, A., and Querol, X.: Urban $\mathrm{NH}_{3}$ levels and sources in a Mediterranean environment, Atmos. Environ., 57, 153-164, 2012.

Rodriguez, M. A., Barna, M. G., Gebhart, K. A., Hand, J. L., Adelman, Z. E., Schichtel, B. A., Collett Jr., J. L., and Malm, W. C.:
Modeling the fate of atmospheric reduced nitrogen during the Rocky Mountain Atmospheric Nitrogen and Sulfur Study (RoMANS): Performance evaluation and diagnosis using integrated processes rate analysis, Atmos. Environ., 45, 223-234, 2011.

Schiferl, L. D., Heald, C. L., Nowak, J. B., Holloway, J. S., Neuman, J. A., Bahreini, R., Pollack, I. B., Ryerson, T. B., Wiedinmyer, C., and Murphy, J. G.: An investigation of ammonia and inorganic particulate matter in California during the CalNex campaign, J. Geophys. Res.-Atmos., 119, 1883-1902, 2014.

Schwartz, J. and Neas, L. M.: Fine particles are more strongly associated than coarse particles with acute respiratory health effects in schoolchildren, Epidemiology, 11, 6-10, 2000.

Shelef, M. and Gandhi, H. S.: Ammonia Formation in the Catalytic Reduction of Nitric Oxide, III. The Role of Water Gas Shift, Reduction by Hydrocarbons, and Steam Reforming, Product R\&D, 13, 80-85, 1974.

Shephard, M. W., McLinden, C. A., Cady-Pereira, K. E., Luo, M., Moussa, S. G., Leithead, A., Liggio, J., Staebler, R. M., Akingunola, A., Makar, P., Lehr, P., Zhang, J., Henze, D. K., Millet, D. B., Bash, J. O., Zhu, L., Wells, K. C., Capps, S. L., Chaliyakunnel, S., Gordon, M., Hayden, K., Brook, J. R., Wolde, M., and Li, S.-M.: Tropospheric Emission Spectrometer (TES) satellite observations of ammonia, methanol, formic acid, and carbon monoxide over the Canadian oil sands: validation and model evaluation, Atmos. Meas. Tech., 8, 5189-5211, doi:10.5194/amt-8-5189-2015, 2015.

Skamarock, W. C., Klemp, J. B., Dudhia, J., Gill, D. O., Barker, D. M., Wang, W., and Powers, J. G.: A description of the advanced research WRF version 2, DTIC Document, 2005.

Sun, K., Cady-Pereira, K., Miller, D. J., Tao, L., Zondlo, M. A., Nowak, J. B., Neuman, J., Mikoviny, T., Müller, M., and Wisthaler, A.: Validation of TES ammonia observations at the single pixel scale in the San Joaquin Valley during DISCOVERAQ, J. Geophys. Res.-Atmos., 120, 5140-5154, 2015.

Sutton, M. A., Dragosits, U., Tang, Y. S., and Fowler, D.: Ammonia emissions from non-agricultural sources in the UK, Atmos. Environ., 34, 855-869, 2000.

Sutton, M. A., Erisman, J. W., Dentener, F., and Möller, D.: Ammonia in the environment: from ancient times to the present, Environ. Pollut., 156, 583-604, 2008.

Sutton, M. A., Reis, S., Riddick, S. N., Dragosits, U., Nemitz, E., Theobald, M. R., Tang, Y. S., Braban, C. F., Vieno, M., and Dore, A. J.: Towards a climate-dependent paradigm of ammonia emission and deposition, Philos. T. Roy. Soc. B, 368, 20130166, 2013.

Theil, H.: A Rank-Invariant Method of Linear and Polynomial Regression Analysis, in: Henri Theil's Contributions to Economics and Econometrics, edited by: Raj, B. and Koerts, J., Advanced Studies in Theoretical and Applied Econometrics, Springer Netherlands, 345-381, 1992.

Thompson, T. M., Rodriguez, M. A., Barna, M. G., Gebhart, K. A., Hand, J. L., Day, D. E., Malm, W. C., Benedict, K. B., Collett, J. L., and Schichtel, B. A.: Rocky Mountain National Park reduced nitrogen source apportionment, J. Geophys. Res.-Atmos., 120, 4370-4384, 2015.

Todd, R. W., Cole, N. A., Waldrip, H. M., and Aiken, R. M.: Arrhenius equation for modeling feedyard ammonia emissions using temperature and diet crude protein, J. Environ. Qual., 42, 666671, 2013. 
USEPA: National Emission Inventory - Ammonia Emissions from Animal Husbandry - Draft Report, US Environmental Protection Agency, Washington, D.C., January 30, 2004.

USEPA: Guidance on the use of models and other analyses for demonstrating attainment of air quality goals for ozone, $\mathrm{PM}_{2.5}$, and regional haze, EPA-454/B07-002, 2007.

Van Damme, M., Wichink Kruit, R., Schaap, M., Clarisse, L., Clerbaux, C., Coheur, P. F., Dammers, E., Dolman, A., and Erisman, J.: Evaluating 4 years of atmospheric ammonia $\left(\mathrm{NH}_{3}\right)$ over Europe using IASI satellite observations and LOTOS-EUROS model results, J. Geophys. Res.-Atmos., 119, 9549-9566, 2014.

Van Damme, M., Clarisse, L., Dammers, E., Liu, X., Nowak, J. B., Clerbaux, C., Flechard, C. R., Galy-Lacaux, C., Xu, W., Neuman, J. A., Tang, Y. S., Sutton, M. A., Erisman, J. W., and Coheur, P. F.: Towards validation of ammonia $\left(\mathrm{NH}_{3}\right)$ measurements from the IASI satellite, Atmos. Meas. Tech., 8, 15751591, doi:10.5194/amt-8-1575-2015, 2015.

Walker, J. T., Whitall, D. R., Robarge, W., and Paerl, H. W.: Ambient ammonia and ammonium aerosol across a region of variable ammonia emission density, Atmos. Environ., 38, 1235-1246, 2004.
Whitburn, S., Van Damme, M., Kaiser, J. W., Van Der Werf, G. R., Turquety, S., Hurtmans, D., Clarisse, L., Clerbaux, C., and Coheur, P.-F.: Ammonia emissions in tropical biomass burning regions: Comparison between satellite-derived emissions and bottom-up fire inventories, Atmos. Environ., 121, 42-54, 2015.

Whitburn, S., Van Damme, M., Clarisse, L., Bauduin, S., Heald, C., Hadji-Lazaro, J., Hurtmans, D., Zondlo, M., Clerbaux, C., and Coheur, P. F.: A flexible and robust neural network IASI-NH retrieval algorithm, J. Geophys. Res.-Atmos., 121, 6581-6599, doi:10.1002/2016JD024828, 2016.

Zbieranowski, A. L. and Aherne, J.: Spatial and temporal concentration of ambient atmospheric ammonia in southern Ontario, Canada, Atmos. Environ., 62, 441-450, 2012.

Zhu, L., Henze, D., Cady-Pereira, K., Shephard, M., Luo, M., Pinder, R., Bash, J., and Jeong, G. R.: Constraining US ammonia emissions using TES remote sensing observations and the GEOS-Chem adjoint model, J. Geophys. Res.-Atmos., 118, 3355-3368, 2013. 